\title{
Environmental liability
}

Citation for published version (APA):

Faure, M. G. (2009). Environmental liability. In M. Faure (Ed.), Tort Law and Economics (pp. xlii +521 ). Edward Elgar Publishing.

Document status and date:

Published: 01/01/2009

Document Version:

Publisher's PDF, also known as Version of record

\section{Document license:}

Taverne

\section{Please check the document version of this publication:}

- A submitted manuscript is the version of the article upon submission and before peer-review. There can be important differences between the submitted version and the official published version of record.

People interested in the research are advised to contact the author for the final version of the publication, or visit the DOI to the publisher's website.

- The final author version and the galley proof are versions of the publication after peer review.

- The final published version features the final layout of the paper including the volume, issue and page numbers.

Link to publication

\footnotetext{
General rights rights.

- You may freely distribute the URL identifying the publication in the public portal. please follow below link for the End User Agreement:

www.umlib.nl/taverne-license

Take down policy

If you believe that this document breaches copyright please contact us at:

repository@maastrichtuniversity.nl

providing details and we will investigate your claim.
}

Copyright and moral rights for the publications made accessible in the public portal are retained by the authors and/or other copyright owners and it is a condition of accessing publications that users recognise and abide by the legal requirements associated with these

- Users may download and print one copy of any publication from the public portal for the purpose of private study or research.

- You may not further distribute the material or use it for any profit-making activity or commercial gain

If the publication is distributed under the terms of Article $25 \mathrm{fa}$ of the Dutch Copyright Act, indicated by the "Taverne" license above, 


\title{
Maastricht University
}

\section{Faculty of Law}

\section{Environmental Liability}

\author{
Michael Faure
}

All rights reserved. No parts of this paper may be reproduced in any form without the permission of the author(s).

This paper can be downloaded without charge from the Social Science Research Network electronic library. 


\section{Environmental liability}

\section{Michael Faure}

\subsection{Introduction}

This chapter of the Encyclopedia on tort law and economics will deal with the hot issue of environmental liability. Economic analysis of law has long been applied to environmental problems and also to the area of environmental liability. As such, the application of the general economic principles of accident law to environmental problems does not pose specific difficulties. There are, however, several characteristics of environmental pollution which make it worthwhile to devote a separate chapter to this area. The problems of choosing between negligence and strict liability may have specific features in the area of environmental liability; environmental damage assessment may be even more difficult in this area and causation issues may play a particular role here as well. Moreover, the foreseeability requirement will often not be met in the case of environmental pollution, which raises specific questions when tort law is applied to environmental pollution. In these cases, one often notices tensions between the deterrence objective stressed by economists and notions of distributional justice advanced by lawyers and policy makers who wish to seek relief for victims of environmental pollution. Many of the issues concerning environmental pollution which are dealt with in this chapter therefore closely relate to issues dealt with in other chapters as well. The general theory (for example, concerning the choice between negligence and strict liability) will therefore not be repeated within the scope of this chapter, but some specific features of environmental pollution will be stressed.

Of course, when confronted with a broad notion such as 'environmental liability' the question always arises how one can delineate the subject. I have chosen on the one hand a broad interpretation, by not only discussing liability issues in the strict sense, but also looking at compensation issues. Therefore, some attention will also be paid to insurance issues and to alternative compensation mechanisms. A central question in the economic analysis of environmental liability is indeed how the law can provide incentives for prevention of environmental pollution and how ex post compensation may be provided at the lowest cost. On the other hand, it is, of course, not possible to discuss all relevant topics related to the domain of environmental liability. We will therefore not discuss the role of environmental groups which could bring citizen suits (see 
on this issue Settle et al., 2001) and moreover an attempt will only be made to focus on the main literature, without being comprehensive. The question of environmental liability was briefly discussed in the chapter on environmental regulation in the previous version of the Encyclopedia (Faure, 2000) and hence this chapter largely builds upon that chapter, of course, by discussing also literature that has been published since that date. In addition to this chapter on environmental liability, included in the volume on tort law and economics, there is also a chapter on environmental crime in the volume of the Encyclopedia on the economics of criminal law and there is a chapter on environmental regulation in the chapter of the Encyclopedia on regulation. Therefore, we will not focus on literature which is related to the area of enforcement, compliance or regulation since the reader can be referred to the chapters in those other volumes for information on those issues. Since we cannot discuss all the vast literature related to this broad area of environmental liability, the reader is referred to the list of references provided at the end of this contribution for further reading.

Some general books discuss problems of environmental liability in some detail. The reader interested in an introduction to the area might for example consult Revesz and Stewart (1995) who provide several contributions with a critical analysis of superfund legislation. Many contributions in Heyes (2001) deal with environmental liability from a law and economics perspective. Bergkamp (2001c) meanwhile discusses issues of environmental liability as do the contributions in Faure (2003a) and Faure and Verheij (2007).

This chapter is structured as follows: after this introduction, first the goals of environmental liability from an economic perspective are discussed (Section 10.2) and the importance of the Coase Theorem is stressed (Section 10.3). Then, the classic dichotomy between negligence and strict liability is applied to environmental pollution (Section 10.4) and the question of the consequences of the fact that many polluters are subject to regulation is addressed (Section 10.5). Problems of environmental damage are discussed in (Section 10.6) and limits and extensions of liability to others rather than the polluter are discussed in (Section 10.7). The importance of latency and the evolution over time of environmental liability is addressed in Section 10.8. Then, we turn briefly to environmental insurance in Section 10.9 and discuss alternative compensation mechanisms as well in Section 10.10. The literature concerning the application of environmental federalism to environmental liability is discussed in Section 10.11. Finally, two specific areas of environmental liability are discussed, namely, nuclear liability (Section 10.12) and oil pollution (Section 10.13) and a few concluding observations are provided in Section 10.14. 


\subsection{Goals of environmental liability}

The general idea of the economic analysis of law and of accident law more specifically, namely that a legal rule and more particularly a finding of liability will provide incentives for careful behaviour to potential parties in an accident setting has been applied by many to the area of environmental pollution as well (see for example Endres and Staiger, 1996; Wagner, 1999; Monti, 2001; and Gimpel-Hinteregger, 1994). Economists therefore stress, also as far as environmental liability is concerned, the deterrent function of tort law. (Environmental) lawyers on the other hand tend to attach more value to the compensation goal of accident law and also of environmental liability. They see environmental liability rather as an instrument that satisfies the polluter-pays principle and guarantees compensation to victims of pollution. A combination of both approaches, by showing that tort law may serve both the aims of deterrence and corrective justice, has been presented by G. Schwartz (1997).

Without going into these issues in detail, it should be mentioned that many studies have shown that environmental liability does have a deterrent effect in the sense that it influences the behaviour of polluters. For example, Alberini and Frost (2007) found that waste generators do respond to the fact that they can be held liable for the costs of clean-up if the waste disposal site contaminates the environment after closure or abandonment and thus falls under the federal or state superfund legislation. Earlier, Alberini and Austin (2001) also found that the imposition of strict liability in state environmental policies reduced unintended pollution releases. Firms therefore show behavioural responses of avoiding liability when they are strictly liable for releases of hazardous chemicals into the environment. Alberini and Austin also found that in states with strict liability, greater spill severity and frequency, this is also associated with smaller production units (and thus reduced assets) whereas this association is not present in states following negligence-based liability. Much research has also been devoted to the effects of so-called superfund liability under the Comprehensive Environmental Response Compensation and Liability Act (CERCLA). Most of these studies (for example, Sigman, 2001) conclude that liability creates various incentives inter alia towards precaution in managing hazardous wastes and to discourage the development of old industrial sites. However, given the high (mostly legal) costs of superfund, the mere fact that the legislation does give incentives for prevention of waste generation does not necessarily mean that the overall judgment is that the system is efficient.

\subsection{Coase}

In many textbooks on law and economics, pollution is presented as the classic example of an externality. A factory might engage in socially 
beneficial activities such as, for example, the production of pharmaceutical products, but this production process may bring about negative side effects, such as the emission of smoke or waste water. Much of the law and economics literature on environmental law is simply concerned with the two fundamental questions, namely:

- What is the optimal level of emissions?

- How can the law provide incentives to comply with this optimal level?

Traditional economists would answer that the right incentives can be given by imposing a tax on the polluting activity. Since this idea builds on the earlier work of Pigou (1951), this is usually referred to as a Pigovian tax. By equating the marginal tax rate to the marginal costs caused by the harmful activity, the factory would get incentives to reduce pollution in an optimal way. However, in his seminal article 'The Problem of Social Cost', Coase showed that if transaction costs are zero, an optimal allocation of resources will always take place irrespective of the content of the governing legal rule (Coase, 1960). Coase stressed the reciprocal nature of harm, meaning in this particular case that the pollution is not just caused by the harmful emissions of the factory but also by the presence of neighbours who are, for example, injured by the smoke emissions. The crucial question therefore is not how the law should provide incentives to force the factory to reduce emissions. First of all, the question should be asked, which of the two actors (factory or victims) should be limited in their activity (and maybe the answer is both, if both can take optimal precautions).

If it is, for example, established that the factory is emitting smoke causing a harm of 200 to each of the three victims living in its neighbourhood, that there is no feasible way in which the victims could prevent this harm from occurring and that all the emissions could be reduced by installing a filter which costs 500 , the optimal solution is obviously that the filter should be installed. It follows from the Coase theorem that if the conditions are met, the filter will indeed be installed no matter what the content of the legal rule are. If the law holds the factory liable to pay compensation to the victims, the installation of the filter (which costs less than the compensation payments) is obviously in the interest of the factory. But the same result will hold if the factory is not liable and victims bear their own damage. Given the zero transaction cost assumption, they will get together and negotiate with the factory to convince the owners to install the filter. Also, if the victims pay for the filter, the price they pay may be less than the costs they would incur if the emissions took place.

Obviously, the efficient outcome may not follow if one of the parties behaves strategically or if the zero transaction cost assumption is not met. 
In addition, it is clear that the Coase theorem only deals with the efficiency aspect of social problems, not with distributional aspects. Indeed, although the efficient result will hold in both cases (liability or no liability), there is a distributional difference: in the first case the factory pays for the filter; in the second case the victims do. Hence, the contents of the legal rule will matter from the victim's perspective. This may be a reason why, from a policy perspective, the legislator sometimes intervenes to make the polluter liable even in situations where the conditions of the Coase theorem were fulfilled.

This Coase theorem is used by many scholars as a starting point for discussing the role of environmental law and, more generally, the need for legal instruments to control environmental pollution. In this respect, we can refer to Baumol and Oates (1979), Frey (1992), Oates (1983) and to Schulze and D'Arge (1974). A literature overview is presented by Mishan (1971a). The possibilities for Coasean bargaining in the environmental arena have been explored inter alia by Rhoads and Shogren (2001). A drawback of the Coase theorem, especially as far as it relates to environmental problems, is that in real life the situation given in the example of one factory emitting smoke that affects just three victims rarely exists. Usually there are cases of multiple victims where transaction costs will be prohibitive. These drawbacks lead to scepticism concerning the importance of the Coase theorem for environmental problems on the part of, for example, Mishan (1971b) and Kapp (1970). In cases where transaction costs are indeed prohibitive, the Coasian negotiations will not take place and some intervention by the legal system will then remain necessary to reach an internalization of the externality.

Since the pioneering work of Calabresi (1961), Brown (1973), Posner (1972) and Shavell (1980b), economists have stressed the steering function of liability rules. The foresight of being held liable ex post will induce parties in the accident setting to take optimal care. These basic ideas can also be applied to environmental damage. By using liability law, a potential polluter can be given an incentive not to pollute or to invest in cleaning equipment of which the marginal costs equal the marginal benefits of a reduction in additional environmental damage. Many authors have applied these general notions of the economics of accident law to environmental liability and have shown that in the environmental context too tort rules may have this preventive effect (see Michelman, 1971; Bouckaert, 1991; Endres and Staiger, 1996; Faure, 1996). A nice study on a Swedish environmental liability case has been presented by Skogh and Rehme (1998). Since the details of the economics of tort law are discussed elsewhere, we shall now only focus on a few aspects of particular importance for environmental liability from a law and economics angle. 


\subsection{Negligence versus strict liability}

One crucial question is whether environmental liability should be based on strict liability or on a negligence regime. The economic literature generally accepts (Shavell, 1980b, 1987b, p. 8) that both a negligence rule and a strict liability rule will provide a potential polluter with incentives to adopt an efficient care level. However, if the activity level is also taken into consideration, a negligence rule will not be optimal since the activity level is not incorporated into the due care standard which the courts apply. Hence, it is argued in the literature that in a unilateral accident model (where only the behaviour of the injurer influences the accident risk) strict liability will be efficient since it leads both to efficient care and to an optimal activity level. Hence, it has often been argued in the literature that there seems to be an economic rationale behind the tendency in case law and environmental statutes in many legal systems to introduce strict liability for environmental damage: since the victim cannot influence the accident risk, strict liability will be first best to give the potential polluter optimal incentives for accident reduction and, hence, for optimal internalization (see, for example, Endres and Staiger, 1996; Faure, 1995a and for nuclear liability Faure, 1995b). However, if risk aversion of the polluter is assumed, strict liability is only efficient if it is insurable (Endres and Schwarze, 1991).

Environmental pollution can in most cases certainly be considered a unilateral accident, that is, an accident whereby only the injurer can influence the accident risk. In that case, the economic model (Shavell, 1980b) predicts that only strict liability will give the injurer an incentive to adopt both an optimal activity level and to take efficient care. In situations where the victim cannot influence the accident risk, strict liability seems to be the first-best solution to give the potential polluter optimal incentives for accident reduction (Pozzo, 1996). The basic model assumes that the judge has accurate information on the amount of the damage. If courts err in assessing damages, strict liability will lead to underdeterrence (so Cooter, 1984). Moreover, strict liability is efficient only if an injurer is always held to fully pay for the consequences of the accident. If the injurer were insolvent or if the judge were to underestimate the amount of the damage, a negligence rule would be preferred if the judge could at least adequately fix the optimal level of care, even if there were uncertainty concerning the precise amount of the damage (Cooter, 1984). A final nuance on the choice between negligence and strict liability is that specific problems may arise if strict liability is combined with other features which may expand the burden of liability on enterprises. This could more particularly be a shift of the burden of proving causation (see Faure and Hartlief, 1998), joint and several liability and high (punitive) damages for (non-pecuniary) losses. Trebilcock (1987) indicated that it was especially because of these last- 
mentioned features that strict liability regimes in the US were experienced as 'crushing'. Hence, the final judgment on the efficiency of strict liability for environmental harm may also depend upon these other issues, such as causation and the magnitude of damages awarded.

In a few recent papers, some of these ideas are either tested, confirmed or further developed. Endres and Bertram (2006) extend the basic Calabresi and Brown model to a dynamic setting where tort law induces progress in care technology. They examine dynamic incentives generated by alternative liability rules. Their general conclusion is that (with nuances) strict liability does not suffer from distortions as a result of changes in a due care standard (resulting from changes in technology) and therefore strict liability is superior to negligence in the intertemporal context. An overview of the literature concerning the incentive impacts of environmental liabilities is also provided by Earnhart (2004). In various papers Van Egteren and Smith examine the difference between negligence and strict liability in a setting where jurisdictions compete for firms that engage in environmentally risky behaviour. They conclude that (in different settings) strict liability (weakly) dominates the negligence rule (Van Egteren and Smith, 2002; van Egteren, Smith and McAfee, 2004; and van Egteren, Smith and Eckert, 2006).

\subsection{The influence of regulation on liability}

\subsubsection{Criteria for regulation}

Even though in this chapter, we focus on the deterrent effect of environmental liability and hence on the capacity of tort law to internalize environmental costs, the criteria advanced by Wittman (1977), Shavell (1984a, 1984b, 1987a) and by Kolstad, Ulen and Johnson (1990) have to be recalled which indicate when liability rules alone will not provide a sufficient incentive for a firm to take efficient care. In the case of environmental risk, most of these criteria point in the direction of ex ante regulation: information can be obtained more easily by the regulator, there is an insolvency risk and a serious risk of underdeterrence since no liability suit will be brought if, for example, the damage is widespread. This literature indicates that there is a strong case for controlling environmental harm through regulation. In legal practice, regulation plays an important role in controlling environmental harm. Similar economic criteria for regulation are advanced in Ogus's book on regulation (1994, pp. 29-46).

\subsubsection{Necessity of the combination}

We just stated that according to Shavell's criteria there is a strong argument to control the environmental risk through ex ante regulation (or 
taxes). However, in individual cases there can still be damage to the environment. Then again liability under tort comes into the picture and the question has been addressed in the literature how regulation influences the liability system and vice versa. These complementarities between tort law and regulation have more particularly been addressed by Rose-Ackerman (1992a, 1992b, 1996), Faure and Ruegg (1994) and Kolstad, Ulen and Johnson (1990). See on these issues also Arcuri (2001), Burrows (1999), Boyer and Porrini (2001, 2002), Faure (2007a), Ogus (2007) and Schmitz (2000). Rose-Ackerman has also compared US and European experiences in using regulation versus tort law in environmental policy (1995a, 1995b). The first point which is often stressed is that the fact that there are many arguments in favour of ex ante regulation of the environment does not mean that the tort system should not longer be used for its deterrent and compensating functions. One reason to still rely on the tort system is that the effectiveness of (environmental) regulation is dependent upon enforcement, which may be weak. In addition, the influence of lobby groups on regulation can to some extent be overcome by combining safety regulation and liability rules. Moreover, safety regulation, for example emission standards in licences, can be quickly out of date, which also merits a combination with tort rules. See also, on the necessity of adding tort law to regulation, Cane (2002) and Hylton (2002).

\subsubsection{Violation of regulation and liability}

The question then arises whether a violation of a regulatory standard should automatically be considered a fault under tort law and thus lead to liability. Shavell argues that this should not necessarily be the case, so as to avoid some parties who pose lower risks taking wasteful precautions (Shavell, 1984a, pp. 365-6). However, in many legal systems, a breach of a regulatory duty is often considered a fault. This can be understood since the regulation will pass on information to both the parties and to the judge on the efficient standard of care. Thus the statutory standards can be applied to define negligence (Rose-Ackerman, 1992a).

\subsubsection{Compliance with regulation and liability}

A second question is whether following the conditions of regulation, often laid down in a licence, excludes liability. This point of view is usually rejected in most legal systems (Faure and Ruegg, 1984, pp. 55-6). The economic rationale behind this rule is that if compliance with a regulatory standard were to release the operator from liability, there would be no incentive to invest in more care than the regulation asks for, even if additional care could still reduce the expected accident costs beneficially (Shavell, 1984a, p. 365). A second reason is that exposure to liability even in the case of compliance 
with regulatory standards may be an adequate remedy when too lenient standards are set as a result of lobbying. Finally tort law can also be seen as a 'stop gap' for situations not dealt with by statute (Rose-Ackerman, 1992a, p. 123). A problem with this point of view is, however, that it may destroy the uniformity a standard is supposed to bring when judges are allowed in all cases to 'second guess' agency decisions (see Rose-Ackerman, 1992a, p. 124). The issue whether ex post liability and ex ante safety regulation are substitutes or complements has also been addressed by Kolstad, Ulen and Johnson (1990). They show that where there is uncertainty, there are inefficiencies associated with the exclusive use of negligence liability and that ex ante regulation can correct these inefficiencies. In that case, they argue a joint use of ex ante and ex post regulation will enhance efficiency. See, on the issue whether compliance with federal safety statues should have a justificative effect in state tort cases, A. Schwartz (2000).

\subsubsection{Liability and incentive-based instruments}

Finally it should be mentioned that in the literature some attention has been given to the problem of combining tort recovery and effluent fees or tradeable rights. Rose-Ackerman has argued that incentive schemes require a fundamental rethinking of the relationship between tort law and statutory law. She has argued that incentive-based regulatory statutes should preempt tort actions: if fee schedules have been set to reflect the social costs, tort actions would be redundant or even counterproductive (see, for example, Rose-Ackerman, 1992a, p. 128).

\subsection{Damage and damages}

Classic techniques for the valuation of damage will be hard to apply when, for example, an entire ecosystem is endangered as a consequence of certain emissions. Nevertheless a more or less accurate estimation of the damage seems important for several reasons. First of all, the scope of the environmental harm will have a large influence on the optimal level of care required from the potential polluter. Indeed, there is supposed to be a relationship between the magnitude of the harm and the optimal level of care. Hence, it seems important to have some insight into the amount of the damage to be able to fix the level of care required from a potential polluter in an efficient way. Second, for the same reason, it will be important to fix the magnitude of the harm accurately ex post, not only to provide a fair compensation to victims (although it may not always be clear who they are in an environmental case), but also because this fixing of the magnitude of the damage will have an influence on future cases as well.

Economists have established a variety of techniques for valuing environmental damage. One method is the so-called hedonic price technique. 
This is based on the analysis of market data from transactions in private goods and services which are related to the characteristics of the public good under consideration. In other words, in the hedonic price technique the value of changes to the natural environment are analysed by the perceived monetary changes this has caused in markets for the affected goods. It is then, for example, assumed that housing values would reflect the variation in the quality of environmental goods. House prices can be a function of natural surroundings such as the presence of parks and forests. On that basis, an evaluation of environmental improvements could be undertaken based on an estimation of the house price function. This approach has, for example, been applied by Hoch and Drake (1974), Harrison and Rubinfeld (1978) and Nelson (1978) (for a critical analysis, see Maler, 1977).

The alternative is to ask individuals to state their willingness to pay for environmental improvement directly, using a survey questionnaire. This is referred to as contingent valuation and is based on a hypothetical allocation procedure for the particular public good. This more direct approach is based on, for example, Davis (1963), Bradford (1970) and Bohm (1971) (for a comparison of both methods of analysis see Pommerehne, 1988). There is a lot of discussion of contingent valuation in the US since it is being used under some environmental laws (see, for a critical analysis, Hausman, 1993). Another option is the use of travel cost studies to estimate environmental benefits. Travel cost studies have been used to treasure the benefits of recreational options (see, for example, Krutilla, 1967).

In order to evaluate the effectiveness of restoration of contaminated sites, a concept of Net Environmental Benefit Analysis (NEBA) has been developed. This technique measures the net environmental benefits in gains attained by remediation minus the value of adverse environmental effects caused by those actions (Efroymson et al., 2004). The damage assessment and valuation under natural resources damages law in the US is extensively discussed by Boyd (2003). An example of how such an economic valuation of ecological losses is performed in practice is presented in a case study by Chapman and Hanemann (2001).

A specific feature of environmental liability regimes, especially under international conventions, is that the compensation due to victims is limited through so-called financial caps. This is usually justified on insurance grounds. Nevertheless, these financial caps have been seriously criticized both in legal and in law and economics literature. Lawyers argue that caps seriously limit the rights of victims to full compensation. From an economic point of view, this is a problem as well since there will be no full internalization of the risky activity. Furthermore Landes and Posner (1984) have argued that if the statutory limit is lower than the potential magnitude 
of the accident, a problem of underdeterrence will arise. Moreover, insurability should not be an argument to introduce financial caps in environmental liability legislation. Liability can be unlimited and a possible duty to insure may be limited to an uninsurable amount (Faure, 1995b).

\subsection{Moving beyond the original polluter}

The classic model of tort law assumes that it is only the polluter who directly caused the environmental harm who will be held liable to compensate the victim. However, in practice, many deviations from this rather straightforward principle can be found whereby others rather than the direct polluter are held liable and liability is therefore shifted to other actors who may have some relationship to the pollution. The reason may be that the original polluter either cannot be identified or is insolvent. In other cases, there is uncertainty concerning the causal relationship between the damage suffered by the victim and the activity of the polluter. All of these issues are quite relevant in legal practice and therefore merit a brief discussion.

\subsubsection{Causal uncertainty}

In environmental liability, the problem will often arise of uncertainty concerning the causal link between an event (for example, an emission) and a certain outcome (for example, health damage). The question then arises how one should deal with this causal uncertainty if scientific evidence for example reports that there is a 40 percent probability that a certain cancer was caused by the wrongful act, but a 60 percent probability that the cancer came from another source (the so-called background risk). After early law and economics papers, where the importance of the causation issue was stressed (for example, Calabresi, 1975; Shavell, 1980a; and Landes and Posner, 1983), further studies explicitly addressed the problem of causal uncertainty. Shavell (1985) and Kerkmeester (1993) stressed that in case of causal uncertainty the liability of the injurer should be limited to those cases in which he actually caused the harm. Otherwise liability would be experienced by the injurer as 'crushing' or, in economic terms, overdeterrence would take place. This would result if, in our example, the firm were held liable to pay 100 percent damage even though there was only a 40 percent probability that his activity contributed to the harm. Rosenberg (1984), Kaye (1982) and Rizzo and Arnold (1980, 1986) have argued that there should only be liability to the extent that the activity contributes to the accident risk, meaning that on the basis of statistical evidence, the liability rule should be constructed in such a way that the polluter will never be held liable for the background risk (which he did not cause), but only for the so-called excess risk (the contribution of his activity to the risk). The question then arises what kind of legal rule can respect these principles. 
Traditionally, there are two possible rules (for an overview, see Faure, 2003b and Faure and Bruggeman, 2007).

One possibility is to award 100 percent compensation to the victim once a certain threshold is passed, for example a 50 percent probability of causation. This is called a threshold liability (see Miller, 2006). This rule, which has been applied in the US for a long time, is considered to be inefficient and also unjust since it forces a firm to compensate (at least partially) for damage which it can never have caused from a statistical point of view. The alternative is to translate the probability of causation by awarding the victim a proportion of its damage (Bergkamp, 2001a). When there is a 40 percent chance, as was the case in our example, that the harm was caused by the tort, the victim will be awarded 40 percent of his loss. The advantage from an efficiency point of view is that the injurer is precisely exposed to the excess risk which he caused. This rule may also be preferable from the victim's perspective, since in this case he would have received nothing under a threshold liability as the 50 percent threshold had not been passed. The threshold liability is indeed an 'all or nothing' approach. Economic analysis generally holds that only the proportional liability rule will give optimal incentives for accident prevention (Landes and Posner, 1984; Robinson, 1985; Makdisi, 1989 and Faure, 1993). However, some scholars consider this probability of causation approaches a lottery since even scientists would not be able to make an accurate assessment of the probability that a certain activity may cause certain damage (Estep, 1960 and Tribe, 1971). Tribe argued that 'Mathematical evidence is more misleading than helpful'. Even though proportional liability seems to be more generally accepted now in many legal systems (such as recently in the UK and in the Netherlands, both in asbestos cases) there is also criticism (for example, by Nieuwenhuis, 2006).

\subsubsection{Joint and several liability}

An area which is closely related to the issue of causal uncertainty just discussed is the tendency to hold joint tortfeasors jointly and severally liable for all the damage to which their behaviour might have contributed. The reasons for doing so are well known. For the victim it is often difficult to prove a clear causal link with the actions of one particular polluter. This may sometimes lead to alleviations of the burden of proof or to holding several insurers jointly and severally liable. The often debated superfund regime under CERCLA is an example of such a joint and several liability regime. The effects of a joint and several liability are obviously also that the risk of insolvency is shifted to the injurer who will be sued by the victim. Indeed, joint and several liability means that the victim can claim full compensation from one injurer, who can then exercise redress against the other parties who contributed to the loss in proportion to their contribution. 
If, however, the other parties were all insolvent, the one injurer who was the defendant would have to compensate for the total loss, including the losses he has not caused. In addition, the risks of uncertainty concerning the causal link are, under joint and several liability, also shifted to the one injurer who is sued in the particular case. It is sufficient for the victim to sue just one of the many potentially liable insurers and to claim full compensation. If the one injurer does not succeed in proving that others contributed to the loss, the damage will ultimately fall on him.

Although an argument could be made in favour of joint and several liability, namely that ex ante it should provide excellent incentives for mutual monitoring of potential injurers, there seem to be disadvantages as well. Joint and several liability may violate the principles of fair and efficient compensation which hold that an injurer should in principle only be held liable to compensate in proportion to his contribution to the loss. The effects on deterrence largely depend upon the legal regime chosen and upon the insolvency of the injurers. The classic argument in this respect is made by Tietenberg (1989). The effects of various systems of extended liability are also examined by Boyd and Ingberman who argue that under certain conditions, extended liability may promote cost internalization, but that there are serious drawbacks as well (Boyd and Ingberman, 2001). Some hold, however, that joint and several liability may violate the principles of fair and efficient compensation which hold that an injurer should in principle only be held liable to compensate in the proportion to his contribution to the loss (see in this respect Bergkamp, 2001a, who argues that joint and several liability is both unfair and leads to over-deterrence). The law and economics literature generally holds that the effects on deterrence largely depend upon the legal regime chosen and upon the (in)solvency of the injurers. A detailed analysis of joint and several liability when all defendants are fully solvent is provided in a classic paper by Kornhauser and Revesz (1989). Later they refined their analysis for the case of limited solvency of the actors involved (Kornhauser and Revesz, 1990). Hyde et al. considered regulation of multiple polluters when individual emissions are unobservable (Hyde et al., 2000). Feess and Hege (2002) propose a simple liability rule when several agents are jointly responsible for monitoring a risky economic activity or for certifying its security. Their rule does not require estimations of hypothetical accident scenarios or ex ante probabilities. Liability payments are thus dependent only on the actual accident, so that the court can ignore the impact of hypothetical accident scenarios (Feess and Hege, 2002).

Since one of the best-known cases of joint and several liability can be found in CERCLA, which instituted the so-called superfund liability regime, the joint and several liability of the so-called potentially responsible parties (PRPs) is examined in many papers, inter alia by Sigman (2001) and 
by Kornhauser and Revesz (1994) in relation to the question of whether joint and several liability encourages settlements. Whether joint and several liability actually has positive effects on incentives for potentially responsible parties regarding prevention remains unclear.

\subsubsection{Channelling of liability}

There is another feature of some environmental liability statutes and/or conventions where again a deviation can be found from the principle that only the injurer who caused the damage should be held fully liable for the loss. This is the so-called channelling of liability. Whereas with joint and several liability a victim can in principle claim full compensation from any of the multiple injurers, channelling is in fact the reverse: under channelling, the liability is attached to one party who then becomes fully liable for the damage. This channelling, indicating which party will be held liable for the loss, is often exclusive, meaning that the victim can only sue the 'channelled injurer' and not another party who might have contributed to the loss as well. Channelling can also be found in international conventions concerning nuclear liability and oil pollution. In nuclear liability conventions, the liability is channelled to the licensee of a nuclear power plant; in conventions concerning damage caused by marine oil pollution, there is channelling to the tanker owner.

It has been argued that this channelling is inefficient because it has perverse effects on the incentives for care where the liability applies exclusively to one operator (Vanden Borre, 1999). This is the case if channelling means that victims no longer have the right to sue another party who could also influence the accident risk. Excluding that third party from liability is inefficient since his incentives for prevention would be diluted. That effect is obviously reduced if the licensee or operator who would be held liable still has a right of recourse against the third party or if liability could be passed on the basis of contract, for example. In that case, one could argue that the liability is simply transferred and that such a reallocation complies with the principles of the Coase theorem (Trebilcock and Winter, 1997). However, this private reallocation of liability may not always be possible and some of the conventions, moreover, even restrict the possibilities of a right of recourse. Channelling can hence hardly be considered as an efficient mechanism for the prevention of accidents.

\subsubsection{Liability of lenders and producers}

Many law and economics scholars have argued that environmental liability should be extended beyond the liability of the 'direct' polluter. The most important motivation for extending this environmental liability to, for example, producers, contractors and victims is cost-internalization (Boyd 
and Ingberman, 2001). Extending liability to lenders has been defended on economic grounds by Segerson (1993) and is applied in superfund clean-up remedies in the US (Sigman, 1998; Boyer and Porrini, 2001, pp. 250-52). The potential dangers of this extended environmental liability have also been discussed by Boyd and Ingberman (1997a). The economic foundations for extending a liability rule to all producers that have the opportunity to engage in a risky activity are provided by Lewis and Sappington (2001). The economics behind the concept of extended producer responsibility for waste has also been explained by Lidgren and Skogh (1996) and in Faure and Skogh (2003, pp. 156-61).

\subsection{Latency and retroactive liability}

Very often one can observe that a long time elapses between the moment that a tort (for example, an emission) occurs and the moment that the damage manifests itself. This problem of a long time lapse between the harmful event and the damage occurrence is known in the Anglo-American literature as 'latency'; in Europe, this problem is sometimes referred to as the 'long tail risk'. This long time lapse can, by the way, not only be caused by the technical feature that it takes a very long time before some risks manifest themselves. In some cases, victims simply wait a long time before filing their lawsuit or, when they do, legal procedures may take a long time as well. The problem of legal transitions has been analysed in the law and economics literature, more particularly by Kaplow (1986). Some of these issues play an important role in determining the scope of environmental liability.

\subsubsection{Retroactive liability?}

Looking at the efficiency aspect first, one can relatively easily state that the retroactive application of a new standard of care seems contrary to the principle that liability should provide incentives for correct behaviour in the future. If suddenly a certain type of behaviour is considered to lead to liability ex post, whereas this was not the case ex ante, any finding of liability can obviously never affect the incentives for that particular tortfeasor for the future. Retroactive liability therefore does not seem to serve any purpose as far as the prevention of accidents is concerned. It has been shown both in the European (Faure and Fenn, 1999) and in the American context that retroactive liability seems inefficient. Boyd and Kunreuther even held that retroactive liability may weaken the incentive to take precautions against future environmental costs (Boyd and Kunreuther, 1997).

Many examples of retroactive liability nevertheless exist. For example, superfund liability under CERCLA is retroactive: potentially responsible parties may be held liable for activities that took place well before superfund legislation entered into force (Sigman, 2001). The potential liability 
for remedying contaminated sites in Central and Eastern Europe also limits the possibilities for privatization in those countries since potential investors are scared away by the foresight of having to pay for the pollution of the past (Bluffstone and Panayotou, 2000). A similar conclusion concerning the investor's amount of information regarding the extent of past environmental contamination (and the related clean-up costs) and the investor's willingness to pay for a particular enterprise in a bid is also confirmed by Earnhart (2004). A distinction should, of course, be made between retroactive liability on the one hand and liability for future damage, for example future releases of greenhouse gases, on the other hand (so thus Bode and Jung, 2006).

\subsubsection{Changes in the level of care}

A related but still somewhat different issue is how the law should react where new risks emerge or when the standard of care increases (under negligence) through changes in technology. It would be too easy simply to state that the tortfeasor will only be held to comply with the 'old' standard of care and will never be liable for risks which he could not foresee. Indeed, it has equally been stated in the literature that the foresight that there may be liability $e x$ post will obviously provide incentives to obtain information about risk to industrial operators (this point is extensively discussed in Shavell, 1992).

The fact that there may be ex post liability even if technology changes is one of the powerful arguments made in law and economics in favour of liability for so-called development risk. This should give an operator appropriate incentives for investments in research to acquire information about risk and about optimal technologies to prevent risk.

The question, however, arises whether this reasoning can also be used to justify a retrospective change of a liability rule or changes in the standard of care itself. The argument is hence a totally different one if not only the nature of the risk, but the liability rule itself, changes. The economics of tort law assume that future incentives for prevention will be affected, given the legal regime in force. Hence, it is hard to argue that an ex post change in the liability rule will positively affect the incentives for proper behaviour which was not considered wrongful at all at the time when the act was committed by the industrial operator. One can expect an operator to assume that new risks may emerge, but hardly that the content of the law will change. Requiring this would lead to an inefficiently high demand for preventive measures and thus to over-deterrence. Hence, retrospective liability indeed seems problematic, taking into account the deterrent function of tort law.

From this it follows that there is apparently a dilemma: on the one hand it is obviously useful that the standard-setting process in civil law is seen 
as a process of learning whereby the standard of care is not static, but changes dynamically over time (this argument has been stressed by Ott and Schäfer, 1997 and by Endres and Bertram, 2006). It would obviously be wrong to state that due care standards should never change. There may be many reasons, for instance new technological insights, leading judges to the efficient decision that a more stringent standard of care can be applied. This new case law can, moreover, have an important signalling function for other parties in the market who can, after all, adapt their future behaviour. But the question obviously arises what should be done with the individual defendant in the particular case in which a new standard of care is set. Should we sacrifice him for the benefit of a more efficient standard in the future and make him retroactively liable eventhough his behaviour was not considered wrongful at the time when it was committed? A possible way out of this dilemma is to make clear that the standard of care will become more stringent for future cases as a result of changes in technology, but not to hold the defendant in the individual case liable, assuming that the latter could not be aware of this modified care standard.

This approach is known in the American literature as the 'prospective overruling', meaning that a court follows an old duty of care in this particular case (with the result that there is no finding of liability), but announces that it will follow a different decision in the future.

In sum, the discussion above makes it clear that in fact a distinction has to be made (although the issues seem to be confused sometimes) between on the one hand a retrospective application of a new liability regime and on the other hand liability for development risks. A liability regime for risks which are not yet known today is not necessarily inefficient, precisely since, if this is known in advance, it will provide incentives to discover information on these new risks and on the optimal techniques to prevent the risk. In other words: a liability for development risks is not inefficient as long as it may positively influence incentives for prevention and as long as the development risk liability is not a disguised retroactive liability. The state of the art defence has also been addressed in the American context by Boyd and Ingberman (1997b). They show that the 'customary practice test' tends to induce inadequate safety, whereas the 'technological advancement test' tends to induce excessive safety.

\subsection{Insurance of environmental liability}

Obviously, within a discussion of compensation for environmental damage, one should also discuss insurance aspects, since the central focus of this chapter is on environmental liability. Hence, we shall merely summarize the most important research results related to the application of 
insurance theory to environmental damage. Insurability issues in general have been discussed, among others, by Faure (1995a), Karten (1997) and Zeckhauser (1996). See more generally, for an application of traditional liability insurance to environmental liability, Abraham (1988), Kunreuther and Freeman (2001) as well as Cousy (1995). The environmental damage insurance in theory and practice is discussed by Faure (2002) and problems with the insurance of environmental liability are discussed by Faure and Grimeaud (2003) and Faure (2007d).

\subsubsection{Moral hazard}

First, one can note that the general principles underlying any insurance cover must obviously be respected with environmental liability insurance as well. Therefore the devices suggested by, for example, Shavell (1979) must be taken into account. One of these devices consists of still exposing the insured partially to risk, which will often be done through, for example, deductibles or by imposing an upper limit on coverage (the upper limit is therefore necessary not only given the limited capacity of the individual insurer, but also to control moral hazard). In addition, the insurer should monitor the behaviour of his insured as much as possible, adapt the premium accordingly and require specific preventive measures through the policy conditions. Such optimal control of moral hazard obviously requires information on the part of the insurer (Endres and Schwarze, 1991). This may require the specialization of insurers engaged in insuring the environmental liability risk in order to be able to exclude bad risks or reward good risks and require relevant preventive measures. On the role of insurance to promote sustainability, see Stahel (1997). Insurability issues with respect to hazardous waste have been analysed in the contributions in Kunreuther and Gowda (1990). If moral hazard is controlled optimally through the use of the above-mentioned devices, the insured will again behave as if no insurance coverage were available, with the advantage that the disutility of risk is removed from him. The incentives for care-taking are in that case no longer given by liability law since the threat to have to pay compensation to a victim is shifted to the insurance company (Kunreuther and Freeman, 2001, pp. 315-16). In case of insurance, the care-taking of the injurer is achieved through appropriately adapting the policy conditions to the behaviour of the individual insured. This also explains that liability insurance has a very important social function. Under liability insurance, the insurer has to guarantee that the insured will take efficient care and thus have an incentive to avoid accidents. This makes clear that an appropriate control of moral hazard is not only in the interest of the individual insurer, but also of society. If there were no efficient control of moral hazard, insurance would on the whole do more harm than good. 


\subsubsection{Adverse selection}

In the absence of an accurate distinction between good and bad risks, risk pools may become too broad, giving the good risks an incentive to leave the pool, thereby creating the famous risk of adverse selection (Akerlof, 1970). This risk of adverse selection led - according to Priest (1987), but criticized by Viscusi (1991) - to an insurance crisis in the US. Adverse selection will, in other words, arise if potentially responsible parties fail to disclose their true risk profile appropriately, which may endanger the narrowing of risk pools. Rogge holds that in Belgium the financial capacity to insure will be limited precisely because only bad risks will have a demand for insurance. If this cannot be 'compensated' by good risks, an incurable adverse selection would remain (Rogge, 1997, p. 5). Thus 'lack of demand has been matched by lack of supply' (Cowell, 1991, p. 327).

\subsubsection{Latency and retroactive liability}

Another problem we have already referred to (in Section 10.8.1) is latency. When legal standards change over time and new standards are applied to 'old' situations (which will sometimes be the case with liability for soil clean-up), insurance problems may arise. If the risk must be considered to be totally unforeseeable the insurer will not be able to charge a premium ex ante for the specific risk, nor can he require specific preventive mechanisms or set aside reservations for potential losses. On the other hand, insurers principally always deal with uncertainty, so that the risk that the law may change must not under all circumstances be considered as unforeseeable. A specific risk premium could be charged in addition to the actuarily fair premium to cope with this uncertainty problem (Kunreuther, Hogarth and Meszaros, 1993).

Since latency problems will often arise in case of environmental liability, the insurer may want to protect himself against the risk of being held liable today (maybe even on the basis of a retroactive application of new standards) for risks that originated for example 15 or 20 years ago. One possibility often advocated in the literature now and applied in many insurance policies is to change the period of insurance cover. Instead of providing coverage for the period when the harmful event occurred or when the loss originated, insurers now often change to a system whereby the claim must have been filed during the period of insurance cover (a so-called claims-made system). By using this insurance technique, the insurer can exclude the risk of being confronted with claims years after the period of insurance cover. Hence, this 'claims-made policy' allows for an exclusion of the so-called 'long-tail risk' which is typical in the case of environmental liability with latency problems (Katzman, 1988; Hankey, 1994; Spier and Haazen, 1996). 


\subsubsection{Causal uncertainty}

Another problem that may specifically arise in the case of environmental liability insurance is causal uncertainty (also discussed in Section 10.7.1). If, for example, a joint and several liability rule is used, this would mean that the insurer would have to cover risks that were not even caused by his insured. This may cause uninsurability, as has been shown by Abraham in relation to insurance for superfund clean-ups in the US (Abraham, 1988). A similar conclusion is reached by Katzman (1988) and by Bergkamp (2001b). Unless a proportionate liability rule is followed, it is not possible to cover a risk if that would mean that the insurer would not only cover the damage of his own insured parties but also the damage that might possibly have been caused by another party. These tendencies lead to a liability on the part of enterprises for risks that they have not caused themselves (in the case of causal uncertainty) or for risks that were not foreseen at the time when the tort was committed (in the case of retrospective liability). They are largely caused by a hidden redistributive agenda: the wish to provide victim protection no matter what it may cost. These tendencies may be far more problematic from an insurability point of view than the shift towards strict liability itself. Indeed, whereas we argued that strict liability as such is insurable, this is no longer true if retrospective liability is introduced or the risk of causal uncertainty is shifted to the enterprise.

\subsubsection{Compulsory insurance}

We should also point to the fact that the question can arise whether liability insurance for environmental damage should be made compulsory. We can be brief concerning this issue here since the law and economics of compulsory insurance is extensively discussed in the literature (see also Faure and Van den Bergh, 1989; Jost, 1996; Skogh, 1989b). In this respect we should only point out that some legal systems, for example Germany, have imposed a duty to insure on certain operators for environmental harm. The efficiency of such a duty and other aspects are analysed by Endres and Schwarze (1991) and Wagner (1991, 1992, 1996), specifically relating to the German Environmental Liability Act.

The traditional economic argument in favour of a duty to insure (or a duty to provide other financial guarantees) is usually the underdeterrence problem which could result from polluters being judgment-proof (Shavell, 1986). By introducing a duty to purchase insurance coverage for the amount of the expected loss, better results will be obtained than with insolvency whereby the magnitude of the loss exceeds the injurer's assets (Kunreuther and Freeman, 2001, p. 316). An overview of economic criteria for compulsory insurance is provided by Faure (2006); an overview of 
financial techniques to guarantee financial assurance for environmental obligations is provided by Boyd (2002).

\subsubsection{Disaster insurance}

Recently, there have been many studies that examine insurance in a related area, more particularly natural disasters. The literature found that individuals generally have no adequate demand, for example for flood insurance (Kunreuther, 1996; Zeckhauser, 1996, p. 135) or for earthquake insurance (Kunreuther, Doherty and Kleffner, 1992). Empirical evidence shows that individuals take an 'it will not happen to me attitude' (Kunreuther, 1996, p. 175; Epstein, 1996, p. 293; Zeckhauser, 1996, p. 115). The data reveal that in Europe too, there is a serious lack of demand for disaster coverage (Schwarze and Wagner, 2004). Some claim that this may be the case because victims count on government relief, so that market failure becomes a self-fulfilling prophecy as a result of misguided regulation (Epstein, 1996, p. 305).

Because of the bounded rationality problems (Kunreuther, 1996, p. 175), many have argued that the perceived risk of hazards could be increased by introducing a mandatory purchase of disaster coverage in addition to small but likely losses (Slovic, Kunreuther and White, 2000, p. 15). Thus recently many have proposed a mandatory type of disaster coverage (Schwarze and Wagner, 2004; Priest, 1996, pp. 225-6 and Kunreuther, 2006). It is the type of coverage which today exists inter alia in France (see Faure, 2007b and 2007c).

\subsection{Other compensation mechanisms}

Increasingly, a lot of attention is paid to other mechanisms that could be used to cover environmental damage. Some believe that the insurance problems mentioned above are so important that insurance can in the end only play a small role in covering the environmental risk. Especially as far as financing clean-up of polluted sites is concerned, many have argued that alternative financial schemes must be investigated other than traditional liability and insurance.

Skogh (1982, 1989a) and Hansson and Skogh (1987) have stressed that when the two policy goals of optimal prevention and optimal compensation have to be fulfilled, the policy maker can choose between either liability rules with private insurance on the one hand, or safety regulation and public compensation mechanisms on the other. This literature develops criteria for when public compensation mechanisms, such as compensation funds, might show comparative benefits. Faure and Hartlief (1996) have argued that no matter how a compensation mechanism is organized, the incentives for prevention of damage should always remain untouched. Hence, the costs of harmful behaviour should as far as possible be 
attributed to the one who caused the harm and a system of risk differentiation should be included in the financing system as well. Therefore, a public compensation mechanism should still provide incentives for prevention by forcing only those who actually contributed to the damage to contribute to the fund, for example.

Obviously, an alternative compensation mechanism for environmental damage could take various forms. One possibility one could think of would be mutual risk-sharing by operators. In the case of very technical risks, operators might for instance have better information on the risk than an insurance company or an administrative agency. Hence, the accident risk could be reduced via an optimal mutual monitoring of the operators. There has been wide experience with these risk-sharing agreements in the field of compensation for oil pollution. This is provided by the so-called Protection and Indemnity Clubs (P\&I Clubs), which are based on a mutual risk-sharing between tanker owners (see, for example, Coghlin, 1984). Faure and Skogh (1992) have argued that a risk-sharing agreement between nuclear power plant operators could also lead to better monitoring and provide higher amounts of compensation for victims than traditional insurance. There is some evidence that risk-sharing agreements will indeed be used in the revision of the Paris and Vienna Conventions on Nuclear Liability (Faure, 1995b).

Compensation funds are also advanced in some cases to cover the insolvency of insurance companies. These so-called guarantee funds usually intervene when traditional insurance fails for some reason. In those cases, a guarantee fund is usually applied in combination with traditional insurance; the fund then intervenes only, for example, when for some reason there is no insurance cover (for the basic argument see Finsinger, 1996). The third type of fund is a public compensation mechanism that really takes the place of traditional insurance because the particular risk may be uninsurable. In the environmental context, one can think of situations for which no individual injurer can be made liable, for example the degradation of a particular habitat caused by acid rain. Inevitably, the question arises how the fund can be financed, taking into account the causes of the particular pollution problem. If it is clear that, for example, sulphur dioxide emissions caused the particular problem from an economic point of view, one could argue that a tax should be introduced on the polluting activity which could be used to finance the compensation fund. This was basically the idea behind one of the major environmental funds known today, namely the American superfund introduced by CERCLA. The law and economics of the superfund experience has been analysed in a book edited by Revesz and Stewart (1995). This book provides a valuable insight into the economics of the superfund system, addressing issues such as the applicable liability regime, the role of the insurance industry, clean-up 
standards and more particularly the transaction costs involved in the current superfund regime.

Other no-fault compensatory alternatives for environmental injuries are discussed by Dewees, Duff and Trebilcock (1996, pp. 328-31). They also discuss both compensation for oil pollution and nuclear liability, although they rightly stress that the American Price-Anderson Act (on nuclear liability) was largely motivated by a desire to allow the development of a nuclear power industry. They show little enthusiasm for an environmental disease compensation fund, arguing that many of the problems of the liability system, for example causal uncertainty, would not be removed by the instalment of a fund. Indeed, the administrative agency handling the fund would have to determine whether an individual disease is caused by the specific pollutant, which might render the administration of such a fund difficult and expensive. An overview of alternative compensation mechanisms for environmental damage is also provided by Radetzki and Radetzki (2000) and by Faure (2004). In Europe, there are some experiments introducing environmental compensation funds on a rather small scale (for an overview, see Bocken, 1987, 1988, 1990, 1991). Again, the question of adequate compensation is now often raised in the context of a related area to environmental liability, namely disaster relief. In practice, governments often intervene either on ad hoc basis or through a structural fund to provide relief for the victims of catastrophes. These solutions, whereby public means are randomly used to compensate victims, have been seriously criticized by law and economic scholars for being insufficiently capable of providing the same level of incentives for prevention as risk differentiation under insurance (Epstein, 1996, p. 297; Priest, 1996; Kaplow, 1991). Gron and Sykes (2002) similarly argue that a structural compensation fund may send the wrong signal to the market: it will provide them with few incentives to develop financial solutions themselves (see also Endres, Ohl and Rundshagen, 2003, p. 290, who argue that disaster victims can then free-ride on the state). In the words of Gollier: 'Solidarity kills market insurance' (Gollier, 2005, p. 25).

Some have provided general overviews of alternative compensation mechanisms, especially to deal with catastrophic (environmental) risks. See in that respect, for example, Radetzki and Radetzki (2000) and Faure (2004). Faure (2002 and 2007d) discusses particular shifts towards alternative compensation mechanisms for environmental damage, such as direct environmental insurance and risk-sharing agreements.

\subsection{Environmental federalism and environmental liability}

There is a body of literature that generally discusses the application of the economics of federalism to environmental issues. That literature is 
discussed in the chapter on environmental regulation within the volume of the Encyclopedia on regulation. Some papers also deal with the specific question of whether environmental liability legislation should be shifted to the central level within a federal structure (see, for example, Faure and De Smedt, 2002). The general tenor of this literature is that harmonization may be indicated when transboundary externalities are at stake that cannot otherwise be cured or when an incurable race-to-the-bottom would emerge as a result of destructive competition between states to attract industry with lenient environmental liability rules. Many have applied these theoretical insights,for example to the question of whether environmental liability should be harmonized within Europe. Van Egteren and Smith (2001, 2002), Van Egteren, Smith and McAfee (2004) and Van Egteren, Smith and Eckert (2006) examine these issues with respect to the desirability of harmonization of environmental liability in the European Union. They conclude that if jurisdictions were to delegate standard setting to a central authority (as in the European Union), this would not implement the socially optimal outcome. However, they also demonstrate that if harmonization of environmental regulation were to be introduced, it would make more sense if strict liability were used rather than a simple negligence rule. Alberini and Frost (2007) conclude that the creation of a European environmental liability regime in the European Union may not necessarily negate the effects of country-specific liability regimes. This complies with critical studies by Bergkamp (2000, 2001a, 2001b, 2001c, pp. 381-2, 2002 and 2005) who similarly argue that there are no reasons for the harmonization of environmental liability within Europe.

Notwithstanding these warnings from law and economics scholars, on 21 April 2004 Directive 2004/35/CE on Environmental Liability was adopted. A few later studies critically review the Directive from a law and economics perspective and more particularly concerning the question whether environmental liability needed to be harmonized at a European level (Bergkamp, 2005; De Smedt, 2007a and 2007b).

\subsection{The nuclear risk}

There are two types of environmental risks that deserve a short separate treatment since there is some literature dealing specifically with nuclear risks and oil pollution. Obviously, most of the problems addressed so far apply to these two risks as well, so we shall simply report on some of the literature addressing specific issues concerning these risks.

As far as the nuclear risk is concerned, Nichols and Wildavsky (1987), Feinstein (1989) and Paté-Cornell (1987) stress the specific character of the nuclear risk, namely the low probability of an accident and the difficulties of probabilistic risk assessment in quantifying risk at nuclear power 
plants. Feinstein examines the safety records of US nuclear power plants and found a sharp increase in detection of violations following the Three Mile Island accident.

Special attention has equally been given to nuclear liability and the insurance of the nuclear risk. Taking into account the economic test for strict liability, nuclear accidents pose a strong case in favour of strict liability, since these accidents are typically unilateral (Faure, 1995b). Most international conventions on nuclear liability also adopted a strict liability rule. However, in many legal systems the compensation due to victims is also statutorily limited to relatively low amounts. Here we can refer to the discussion of financial caps above: these are largely inefficient, lead to underdeterrence and undercompensation of victims (Trebilcock and Winter, 1997).

As far as nuclear insurance is concerned, it should be mentioned that in most legal systems, insurance is provided by national nuclear pools, which have brought resources together on a non-competitive basis and offer relatively low amounts for third-party insurance. This liability-insurance scheme for the nuclear risk can to a large extent be explained as the result of lobbying by the nuclear industry (Faure and Van den Bergh, 1990). The conventions on nuclear liability which were drafted in the 1960s had as their main goal to guarantee that nuclear power could further develop and that the nuclear industry would be protected against high claims. Hence, strict liability was combined with relatively low caps, also to make the nuclear risk insurable. An alternative compensation mechanism would be the pooling of risks by operators, based on a risk-sharing agreement whereby a mutual monitoring between plant operators would guarantee prevention and higher amounts of compensation could be made available (Faure and Skogh, 1992).

Vanden Borre has criticized the so-called channelling of liability. This means that only the licensee of a nuclear power plant can be held liable for the damage caused by a nuclear accident; the liability of all others who might also have contributed to the nuclear risk is hence excluded (Vanden Borre, 1999). In his dissertation, Vanden Borre (2001) also criticizes the compensation system for nuclear risks in international conventions, arguing that this leads to serious underdeterrence and undercompensation (Vanden Borre, 2001). Vanden Borre has also compared the compensation for nuclear accidents in international conventions with the compensation provided in the United States under the Price-Anderson Act and concludes that the US Price-Anderson Act is, also from an economic perspective, to be preferred to the international regime since Price-Anderson is no longer based on government intervention and involves a second layer of compensation paid by the collectivity of all nuclear operators. Hence, substantially 
larger amounts are generated in the US than in the international regime (Vanden Borre, 2007).

Recently, a similar conclusion was reached by Fiore (2007), who similarly argues in her dissertation that the current international regime of compensation for damage caused by nuclear plants insufficiently internalizes the nuclear risk. This is due on the one hand to the financial limit (cap) on the liability of the operator of a nuclear plant and on the other hand to the fact that, in the international regime, there is a large amount of compensation provided by the state(s), which in fact amounts to a subsidy to nuclear power. Earlier, it had also been argued with respect to the US PriceAnderson Act that the limit on the liability of nuclear operators in fact constitutes a subsidy to the industry. Dubin and Rothwell (1990) valued the amount of the subsidy under the Price-Anderson Act at $\$ 60,000,000$ per reactor (and \$22,000,000 following the 1988 amendments). Heyes and Liston-Heyes (1998) criticized Dubin and Rothwell's calculation and came up with lower amounts.

Finally, it should also be mentioned that in the case of the nuclear risk many problems of causal uncertainty will arise. Usually a probability of causation formula is used to investigate the likelihood that a certain disease (for example, cancer) was caused by a certain exposure to radiation (Bond, 1981; Ketchum, 1985). However, in practice it is often very difficult to establish this probability of causation: data on these probabilities in individual cases are certainly not conclusive (Estep, 1960; Meddler and Moselly, 1985; Van Mieghem, 1988).

\subsection{Marine oil pollution}

Marine oil pollution is also an issue which received attention in the literature, even before environmental problems were analysed at a general level. Economists have always been interested in the question of how accidental or voluntary marine oil pollution by tankers could be prevented optimally either by investments in the safety of the tankers (in case of accidental pollution) or by increasing detection (in case of voluntary discharge) (see, for example, Burrows, Rowley and Owen, 1974). The problem of detection of oil spills has been modelled by Epple and Visscher (1984). They show how vessel size, the price of oil, the enforcement of pollution control regulations and the risk associated with variance in spill size affect the oil transporters' decisions concerning expenditures on measures for spill prevention. They provide empirical data to support their theoretical analysis. Cohen (1987) has followed up on their work by providing an optimal enforcement strategy to prevent oil spills. We can also point to a paper by Dunford (1992) on the natural resource damages from oil spills that addresses the question of under what kind of conditions there can be liability under the US Oil 
Pollution Act for natural resource damages. The recovery for economic loss following the Exxon Valdez oil spill has been examined by Goldberg (1994).

One important weakness in the enforcement of marine oil pollution is the fact that the so-called Protection and Indemnity Clubs provide full insurance for the fines which are imposed (Lomas, 1989). However, Faure and Heine (1991) have argued that it is not the insurance itself which poses the problem, but the low probability of detection, which causes a low expected fine.

Furthermore, we can point to the fact that the liability regime for oil pollution is governed by international conventions that have a similar legal structure to the conventions on nuclear liability: strict liability with financial caps. Insurance is provided through the Protection and Indemnity Clubs, mutual insurance companies of the ship-owning companies, which is typically different from the nuclear liability sphere (see Bongaerts and De Bièvre, 1987). These oil pools are not inefficient as such and costly government regulations would not be able to improve efficiency to a large degree (see Libecap and Wiggins, 1984; Ault and Ekelund, 1988, p. 75). Another major difference from the nuclear liability regime is that in the case of maritime oil pollution, compensation is provided not only through these P\&I clubs, which act as insurance companies, but also through an oil pollution fund, financed by taxes on crude oil. In this case, there is hence combined financing by the oil-producing industry and the ship owners (see on liability for marine oil pollution the contributions in De la Rue, 1993).

Compensation for marine oil pollution under the US Oil Pollution Act and more particularly the financial assurance mechanisms contained in this Act are discussed by Boyd (2002, 2003).

Recently, some critical studies were produced concerning the financial limit on the liability of the tanker owner and on the channelling of liability to this tanker owner. For a general economic analysis of the international oil pollution compensation regime, see Faure and Wang (2006). Also in the dissertation by Hay (2006), a criticism was formulated on the limitation of liability. Hay also shows that notwithstanding important adaptations in the conventions, victims, more particularly after the Erika incident off the coast of Brittany, still remained largely uncompensated.

An overview of the historical evolution of the international marine oil pollution compensation regime is provided by Wang (2007) and the shifts in this compensation regime are identified by Verheij (2007). An empirical analysis of these shifts is provided by Hendrickx (2007) who shows that clean-up operations have become more expensive, more particularly as a result of pressure from environmental groups and public opinion. 
Hendrickx also found that, for a higher proportion of spills, polluters could not be identified. He suspects that, as a result of the strict liability of the tanker owner, they might have improved their skills of concealing their identity (Hendrickx, 2007, p. 257). Given the low liability limits and the increased amount of compensation, Hendrickx equally concludes that a larger proportion of the costs is borne by the International Oil Pollution Compensation Fund. A general overview of vessel-sourced marine pollution (both regulation aiming at prevention and compensation) is provided by Tan (2006).

\subsection{Concluding remarks}

The overview of the literature concerning environmental liability in this chapter has, of course, had to be selective. We have mainly focused on the law and economics literature and even there, it was impossible to be comprehensive. Much more is published in the legal literature on environmental liability as well as in environmental economics dealing with the same topic. Some topics could not be discussed at all within the limited framework of this chapter (for example, the role of citizen suits), whereas other topics could only be briefly touched upon (for example, lender liability).

The overview provided in this chapter nevertheless shows that the application of the general law and economics framework to environmental pollution issues and more particularly to environmental liability has yielded rich results. Many studies apply the general framework of tort law and economics provided in other chapters in this volume (for example, concerning the choice between negligence and strict liability or concerning causation) to environmental liability. In that sense, the environmental area offers a suitable occasion for testing some of the hypotheses discussed in other chapters.

One can indeed observe that in much of the literature refinements of the traditional models have taken place in their application to specific environmental problems. In addition, one can also observe that the theoretical literature on environmental liability has developed strongly in the past 25 years. As a result of these developments, law and economics models have been refined to such an extent that they are much better able to explain (descriptively) existing environmental liability schemes or (normatively) to indicate which improvements are likely to improve social welfare.

Moreover, whereas in some areas one often hears the criticism that law and economics scholars are merely busy with technical refinements to existing models, as far as the domain of environmental liability is concerned, it should be stressed that much of the theoretical developments 
in the literature are also quite relevant for actual environmental policy. One therefore notices that many studies deal, for example, with a critical evaluation of superfund legislation under CERCLA in the US or with the question whether and, if so, how an environmental liability regime should be shaped in Europe. Afterwards, ex post evaluations of those regimes take place as well. Moreover, one also notices that both in the US and in Europe, policy makers increasingly take the law and economics literature in this domain into account. Even though this does, of course, not mean that they will always listen to advice formulated by law and economics scholars, one observes that policy makers often have no difficulties accepting that economics has a useful message on how an environmental liability regime should be shaped. Whereas in domains like family law or criminal law, there may still be opposition to the application of economic notions, in the area of environmental liability, one notices to the contrary that for policy makers it is quite natural to take the findings of law and economics literature into account. Thus one could, for example, notice that in Europe in documents preceding the Directive on Environmental Liability explicit reference was made to the notion that an environmental liability regime should provide potential polluters with incentives for prevention.

Even though one can thus argue that this area of law and economics has gone through a whole development and that there is now an abundant and rich literature addressing various aspects of environmental liability, this, of course, does not mean that there remains no work to be done. First of all, at a theoretical level, there are various issues that undoubtedly merit further research. For example, the particular circumstances under which NGOs can play a role in environmental liability suits certainly deserves more attention. One can easily see the benefits of citizen suits, but there may be particular drawbacks as well. Hence, criteria should be developed to indicate under what circumstances citizen suits can play a positive role in the enforcement of environmental liability rules.

Even though it would be easy to list more topics that need further theoretical research, it is probably more important to focus future research on empirical work as well. Even though environmental liability is again an area where there is probably relatively more empirical work than in some other areas of law and economics, still more could undoubtedly be done. For example, questions still arise as to the precise way in which liability rules affect the behaviour of firms in their decision to invest more in care technology. Even though we have indicated that much empirical literature exists in that respect, many studies are of North American origin and much more could be done in this respect in Asia and Europe as well. Moreover, these empirical studies should also pay attention to the way in which 
compensation mechanisms such as insurance affect the behaviour of firms. Particular attention in that respect should also be given to the fact that (at least in Europe) insurance companies apparently make less effort to differentiate risk than economic theory would predict. The question, of course, arises why this is the case and what the effects of this phenomenon are on the behaviour of firms. Only if more information becomes available on the actual reactions of polluters to changes in liability rules and compensation mechanisms will it also be possible to fine-tune legal rules in such a way that they can often play an optimal role in providing polluters with incentives for the prevention of environmental harm.

Finally, even though we have indicated that environmental liability is an area where policy makers already pay a lot of attention to the lessons from law and economics theory, more could still be done, more particularly at the level of implementation. It is surprising to notice that, for example as far as natural disasters are concerned, some European countries (like Germany, Italy or the Netherlands) apparently prefer to spend large parts of the public budget on random compensation of victims rather than securing facilitative strategies which would stimulate the efficient functioning of insurance markets. Also, it remains remarkable that, at the international level, the nuclear industry still enjoys the same protection as 40 years ago when the nuclear industry was at the beginning of its development and was awarded broad protection (through financial limits) in international conventions. Now that as a result of climate change more countries may be seduced to increase the use of nuclear power, governments may listen more seriously to the lesson from economic theory, namely that nuclear operators too should be forced to internalize the social costs resulting from their activities. The American Price-Anderson Act shows, moreover, that without government subsidy and with a risk-sharing agreement between nuclear operators, much larger amounts of compensation could be generated which would come much closer to realistic compensation amounts than under the international regime. Also the above-mentioned phenomenon of climate change may pose interesting challenges for law and economics scholars. Within the context of this contribution, we refer more particularly to a recent tendency in the literature to examine something which many held impossible, namely the application of liability rules to climate change. Even though this may still pose serious problems (Grossman, 2003; Faure and Nollkaemper, 2007; Tol and Verheyen, 2004; Verheyen, 2005; Spier, 2006), it is an issue which is receiving increasing attention and which may well dominate the research agenda for law and economics scholars interested in environmental liability in the decades to come. 


\section{Acknowledgements}

I am grateful to Karine Fiore for useful comments on an earlier draft of this contribution and to Wanchi Tang for useful research assistance.

\section{Bibliography on environmental liability}

Abraham, K. (1988), 'Environmental Liability and the Limits of Insurance', Columbia Law Review, 88, 949-60.

Akerlof, G. (1970), "The Market for "Lemons": Quality, Uncertainty and the Market Mechanism', Quarterly Journal of Economics, 33, 488-500.

Alberini, A. and D. Austin (2001), 'Liability Policy and Toxic Pollution Releases', in A. Heyes (ed.), The Law and Economics of the Environment, Cheltenham, UK and Northampton, MA, USA: Edward Elgar, pp. 92-115.

Alberini, A. and C. Frost (2007), 'Forcing Firms to Think about the Future: Economic Incentives and the Fate of Hazardous Waste', Environmental \& Resource Economics, 36, 451-74.

Arcuri, A. (2001), 'Controlling Environmental Risk in Europe: The Complementary Role of an EC Environmental Liability Regime', Tijdschrift voor Milieuaansprakelijkheid (Environmental Liability Law Review), 37-45.

Ault, R.W. and R.B. Ekelund, Jr (1988), 'Rent Seeking in a Static Model of Zoning', American Real Estate and Urban Economics Association Journal, 16, 69-76.

Baumol, W.J. and W.E. Oates (1979), Economics, Environmental Policy, and the Quality of Life, New York: Prentice Hall.

Bergkamp, L. (2000), 'The Commission's White Paper on Environmental Liability: A Weak Case for an Easy Strict Liability Regime', European Environmental Law Review, 9, 105-14 and $141-8$.

Bergkamp, L. (2001a), Liability and Environment, The Hague: Kluwer Law International.

Bergkamp, L. (2001b), 'The Proper Scope of Joint and Several Liability', Tijdschrift voor Milieuaansprakelijkheid (Environmental Liability Law Review), 153-5.

Bergkamp, L. (2001c), Liability and Environment: Private and Public Aspects of Civil Liability for Environmental Harm in an International Context, The Hague: Kluwer Law International.

Bergkamp, L. (2002), 'The Proposed Environmental Liability Directive', European Environmental Law Review, 11, 294-313.

Bergkamp, L. (2005), 'The European Environmental Liability Directive and its Effects on Industry and Economy', in R. Mellenbergh and R. Uylenburg (eds), Aansprakelijkheid voor schade aan de natuur, Groningen: Europa Law Publishing, pp. 93-132.

Bluffstone, R.A. and T. Panayotou (2000), 'Environmental Liability and Privatisation in Central and Eastern Europe: Towards an Optimal Policy', Environmental and Resource Economic, 17, 335-52.

Bocken, H. (1987), 'Alternatives to Liability and Liability Insurance for the Compensation of Pollution Damages', Part I, Tijdschrift voor Milieuaansprakelijkheid (Environmental Liability Law Review), 83-7.

Bocken, H. (1988), 'Alternatives to Liability and Liability Insurance for the Compensation of Pollution Damages', Part II, Tijdschrift voor Milieuaansprakelijkheid (Environmental Liability Law Review), 3-10.

Bocken, H. (1990), 'Systèmes Alternatives pour l'Indemnisation des Dommages du à la Pollution', Revue Général des Assurances et des Responsabilités, 11698-714.

Bocken, H. (1991), 'Complementary Compensation Mechanisms. A General Environmental Damage Fund?', in H. Bocken and D. Ryckbost (eds), Insurance of Environmental Damage, Brussels: Story-Scientia, pp. 425-37.

Bode, S. and M. Jung (2006), 'Carbondioxide Capture and Storage - Liability for Nonpermanence under the UNFCCC', International Environmental Agreements, 6, 173-86.

Bohm, P. (1971), 'An Approach to the Problem of Estimating Demand for Public Goods', Swedish Journal of Economics, 73, 55-66. 
Bond, V. (1981), 'The Cancer Risk Attributable to Radiation Exposure: Some Practical Problems', Health Physics, 40, 108-11.

Bongaerts, J.C. and A.F.M. De Bièvre (1987), 'Insurance for Civil Liability for Marine Oil Pollution Damages', Geneva Papers on Risk and Insurance, 12, 145-57.

Bouckaert, B. (1991), 'La Responsabilité Civile Comme Base Institutionelle d'une Protection Spontanée de l'Environnement', Journal des Economistes et des Etudes Humaines, 2, 315-35.

Boyd, J. (2002), 'Financial Responsibility for Environmental Obligations: our Bonding and Assurance Rules fulfilling their Promise?', in T. Swanson (ed.), An Introduction to the Law and Economics of Environmental Policy: Issues in Institutional Design, Amsterdam: JAI Press, pp. 417-85.

Boyd, J. (2003), 'A Market-Based Analysis of Financial Insurance Issues associated with US Natural Resource Damage Liability', in M. Faure (ed.), Deterrence, Insurability, and Compensation in Environmental Liability: Future Developments in a European Union, Vienna: Springer, pp. 258-302.

Boyd, J. and D. Ingberman (1997a), "The Search of Deep Pocket: is "Extended Liability" Expensive Liability?', Journal of Law, Economics, and Organisation, 13, 232-58.

Boyd, J. and D. Ingberman (1997b), 'Should "Relative Safety" be Test of Product Liability?', Journal of Legal Studies, 26, 433-73.

Boyd, J. and D. Ingberman (2001), 'The Vertical Extension of Environmental Liability through Claims of Ownership, Contact and Supply', in A. Heyes (ed.), The Law and Economics of the Environment, Cheltenham, UK and Northampton, MA, USA: Edward Elgar, 44-70.

Boyd, J. and H. Kunreuther (1997), 'Retroactive Liability or the Public Purse?', Journal of Regulatory Economics, 11, 79-90.

Boyer, M. and D. Porrini (2001), 'Law versus Regulation: A Political Economy Model of Instrument Choice in Environmental Policy', in A. Heyes (ed.), The Law and Economics of the Environment, Cheltenham, UK and Northampton, MA, USA: Edward Elgar, pp. 249-79.

Boyer, M. and D. Porrini (2002), 'The Choice of Instruments for Environmental Policy: Liability or Regulation?', in T. Swanson (ed.), An Introduction to the Law \& Economics of Environmental Policy: Issues in Institutional Design, Amsterdam: JAI Press, pp. 245-67.

Bradford, T. (1970), 'Cost Benefit Analysis and Demand Curse for Public Goods', Kyklos, 23, 775-91.

Brown, J.P. (1973), 'Toward an Economic Theory of Liability', Journal of Legal Studies, 2, 323-49.

Burrows, P. (1999), 'Combining Regulation and Liability for the Control of External Costs', International Review of Law \& Economics, 19, 227-42.

Burrows, P., C.K. Rowley and D. Owen (1974), 'The Economics of Accidental Oil Pollution by Tankers in Coastal Waters', Journal of Public Economics, 3, 251-68.

Calabresi, G. (1961), 'Some Thoughts on Risk Distribution and the Law of Torts', Yale Law Journal, 60, 499-553.

Calabresi, G. (1975), 'Concerning Cause and the Law of Torts', University of Chicago Law Review, 42, 69-108.

Cane, P. (2002), 'Tort Law as Regulation', Common Law World Review, 31, 305-31.

Chapman, D.J. and W.M. Hanemann (2001), 'Environmental Damages in Court: The American Trader Case', in A. Heyes (ed.), The Law and Economics of the Environment, Cheltenham, UK and Northampton, MA, USA: Edward Elgar, pp. 319-67.

Coase, R.H. (1960), 'The Problem of Social Cost', Journal of Law and Economics, 3, 1-44.

Coghlin, T.G. (1984), 'Protection and Indemnity Clubs', Lloyds Maritime and Commercial Law Quarterly, 11, 403-16.

Cohen, M.A. (1987), 'Optimal Enforcement Strategy to Prevent Oil Spills: An Application of a Principal-Agent Model with Moral Hazard', Journal of Law and Economics, 30, 23-51.

Cooter, R. (1984), 'Prices and Sanctions', Columbia Law Review, 84, 1343-523. 
Cousy, H. (1995), 'Recent Developments in Environmental Insurance', in F. Abraham, K. Deketelaere and J. Stuyck (eds), Recent Economic and Legal Developments in European Environmental Policy, Leuven: Acco, pp. 227-41.

Cowell, J. (1991), 'Compulsory Environmental Liability Insurance', in H. Bocken and D. Ryckbost (eds), Insurance of Environmental Damage, Antwerp: Kluwer, pp. 317-30.

Davis, R.K. (1963), 'Recreation Planning as an Economic Problem', National Resources Journal, 3, 239-49.

De la Rue, C.M. (1993), Liability for Damage to the Marine Environment, London: Lloyd's of London Press Ltd.

De Smedt, K. (2007a), 'Shifts in Compensation for Environmental Damage: From Member States to Europe', in M. Faure and A. Verheij (eds), Shifts in Compensation for Environmental Damage, Vienna: Springer, pp. 103-31.

De Smedt, K. (2007b), Environmental Liability in a Federal System: A Law and Economics Analysis, Antwerp: Intersentia.

Dewees, D.N., D. Duff and M.J. Trebilcock (1996), Exploring the Domain of Accident Law: Taking the Facts Seriously, Oxford: Oxford University Press.

Dubin, J.A. and G.S. Rothwell (1990), 'Subsidy to Nuclear Power through Price-Anderson Liability Limit', Contemporary Economic Policy, 8 (3), 73-9.

Dunford, R. (1992), 'Natural Resource Damages from Oil Spills', in T.H. Tietenberg (ed.), Innovation in Environmental Policy, Economic and Legal Aspects of Recent Developments in Environmental Enforcement and Liability, Aldershot, UK and Brookfield, USA: Edward Elgar, pp. 165-93.

Earnhart, D. (2004), 'Liability for Past Environmental Contamination and Privatisation', Environmental \& Resource Economics, 29, 97-122.

Efroymson, R.A., J.P. Nicolette and G.W. Suter (2004), 'A Framework for Net Environmental Benefit Analysis for Remediation or Restoration of Contaminated Sites', Environmental Management, 34 (3), 315-31.

Endres, A. and R. Bertram (2006), 'The Development of Care Technology under Liability Law', International Review of Law and Economics, 26, 503-519.

Endres, A., C. Ohl and B. Rundshagen (2003), "“Land unter!" Ein institutionenökonomische Zwischenruf', List Forum für Wirtschafts- und Finanzpolitik, 29, 284-94.

Endres, A. and B. Staiger (1996), 'Ökonomische Aspekte des Umwelthaftungsrecht', in M. Ahrens and J. Simon (eds), Umwelthaftung, Risikosteuerung und Versicherung, Berlin: Erich Schmidt Verlag, pp. 79-93.

Endres, A. and R. Schwarze (1991), 'Allokationswirkungen einer UmweltHaftpflichtversicherung (Allocative Effects of an Environmental Liability Insurance)', Zeitschrift für Umweltpolitik und Umweltrecht, 14, 1-25.

Epple, D. and M. Visscher (1984), 'Environmental Pollution: Modelling Occurrence, Detection, and Deterrence', Journal of Law and Economics, 27, 29-60.

Epstein, R. (1996), 'Catastrophic Responses to Catastrophic Risks', Journal of Risk and Uncertainty, 12, 287-308.

Estep, E. (1960), 'Radiation Injuries and Statistics: The Need for a New Approach to Injury Litigation', Michigan Law Review, 59, 259-304.

Faure, M.(1993), ( G) een Schijn van Kans. Beschouwingen over het Statistisch Causaliteitsbewijs bij Milieugezondheidsschade, Inauguration, Antwerpen: Maklu.

Faure, M. (1995a), 'The Limits to Insurability from a Law and Economics Perspective', Geneva Papers on Risk and Insurance, 20, 454-62.

Faure, M. (1995b), 'Economic Models of Compensation for Damage Caused by Nuclear Accidents: Some Lessons for the Revision of the Paris and Vienna Conventions', European Journal of Law and Economics, 2, 21-43.

Faure, M. (1996), 'Economic Aspects of Environmental Liability: An Introduction', European Review of Private Law, 6, 85-109.

Faure, M. (2000), 'Environmental Regulation', in B. Bouckaert and G. De Geest (eds), Encyclopedia of Law and Economics, II, Civil Law and Economics, Cheltenham, UK and Northampton, MA, USA: Edward Elgar, pp. 443-520. 
Faure, M. (2002), 'Environmental Damage Insurance in Theory and Practice', in T. Swanson (ed.), An Introduction to the Law and Economics of Environmental Policy: Issues in Institutional Design, Amsterdam: JAI Press, pp. 283-328.

Faure, M. (2003a), Deterrence, Insurability, and Compensation in Environmental Liability: Future Developments in the European Union, Vienna: Springer.

Faure, M. (2003b), 'Causal Uncertainty, Joint and Several Liability and Insurance', in H. Koziol and J. Spier (eds), Liber AmicorumPierre Witmer, Vienna: Springer, pp. 79-98.

Faure, M. (2004), 'Alternative Compensation Mechanisms as Remedy for Uninsurability of Liability', The Geneva Papers on Risk and Insurance, 29 (3), 455-89.

Faure, M. (2006), 'Economic Criteria for Compulsory Insurance', The Geneva Papers on Risk and Insurance, 31, 149-68.

Faure, M. (2007a), 'Economics Analysis of Tort and Regulatory Law', in W.H. van Boom, M. Lukas and S.H.R. Kissling (eds), Tort Law and Regulatory Law, Vienna: Springer, pp. 399-415.

Faure, M. (2007b), 'Insurability of Damage Caused by Climate Change: a Commentary', University of Pennsylvania Law Review, 155 (6), 1875-99.

Faure, M. (2007c), 'Financial Compensation for Victims of Catastrophes: A Law and Economics Perspective', Law and Policy, 29 (3), 339-67.

Faure, M. (2007d), 'A Shift toward Alternative Compensation Mechanisms for Environmental Damage?', in M. Faure and A. Verheij (eds), Shifts in Compensation for Environmental Damage, Vienna: Ectil, pp. 74-102.

Faure, M. and V. Bruggeman (2007), 'Causal Uncertainty and Proportional Liability', in L. Tichý (ed.), Causation in Law, Universita Carlova, Prague, pp. 105-21.

Faure, M. and K. De Smedt (2002), 'Should Europe Harmonize Environmental Liability Legislation?', Environmental Liability, 9, 217-37.

Faure, M. and P. Fenn (1999), 'Retroactive Liability and the Insurability of Long-tail Risks', International Review of Law and Economics, 19, 487-500.

Faure, M. and D. Grimeaud (2003), 'Financial Assurance Issues of Environmental Liability', in M. Faure (ed.), Deterrence, Insurability, and Compensation in Environmental Liability: Future Developments in the European Union, Vienna: Springer, pp. 8-255.

Faure, M. and T. Hartlief (1996), 'Compensation Funds versus Liability and Insurance for Remedying Environmental Damage', Review of European Community and International Environmental Law, 5, 321-6.

Faure, M. and T. Hartlief (1998), 'Remedies for Expanding Liability', Oxford Journal of Legal Studies, 18, 681-706.

Faure, M. and G. Heine (1991), 'The Insurance of Fines: The Case of Oil Pollution', Geneva Papers on Risk and Insurance, 16, 39-58.

Faure, M. and A. Nollkaemper (2007), 'International Liability as an Instrument to Prevent and Compensate for Climate Change', Stanford Environmental Law Journal, 43A, 123-79.

Faure, M. and M. Ruegg (1994), 'Standard Setting through General Principles of Environmental Law', in M. Faure, J. Vervaele and A. Weale (eds), Environmental Standards in the European Union in an Interdisciplinary Framework, Antwerpen: Maklu, pp. 39-60.

Faure, M. and G. Skogh (1992), 'Compensation for Damages Caused by Nuclear Accidents: A Convention as Insurance', Geneva Papers on Risk and Insurance, 17, 499-513.

Faure, M. and G. Skogh (2003), The Economic Analysis of Environmental Policy and Law. An Introduction, Cheltenham, UK and Northampton, MA, USA: Edward Elgar.

Faure, M. and R. Van den Bergh (1989), 'Compulsory Insurance for Professional Liability', Geneva Papers on Risk and Insurance, 14, 308-30.

Faure, M. and R. Van den Bergh (1990), 'Liability for Nuclear Accidents in Belgium from an Interest Group Perspective', International Review of Law and Economics, 10, 241-54.

Faure, M. and A. Verheij (2007), Shifts in Compensation for Environmental Damage, Vienna: Springer.

Faure, M. and H. Wang (2006), 'An Economic Analysis of Compensation for Oil Pollution Damage', Journal of Maritime Law and Commerce, 37, 179-217. 
Feess, E. and U. Hege (2002), 'Safety Regulation and Monitor Liability', Review of Economic Design, 7, 173-85.

Feinstein, J.S. (1989), 'The Safety Regulation of U.S. Nuclear Power Plants: Violations, Inspections, and Abnormal Occurrences', Journal of Political Economy, 97, 115-54.

Finsinger, J. (1996), 'The Basic Arguments Relating to Public Guarantee Funds for Insurance', in D. Heremans and H. Cousy (eds), Essays in Law and Economics III, Financial Markets and Insurance, Antwerpen: Maklu, pp. 243-71.

Fiore, K. (2007), Industrie Nucléaire et Gestion au Risque d'Accident en Europe: du Défaut d'Internationalisation à l'Organisation de la Couverture, Ph.D. dissertation, Université Paul Cézanne, 15 December 2007.

Frey, B.S. (1992), Umweltökonomie, Göttingen: Vandenhoeck \& Ruprecht.

Gimpel-Hinteregger, M. (1994), Grundfragen der Umwelthaftung, Vienna: Manz Publishers.

Goldberg, V.P. (1994), 'Recovery for Economic Loss following the Exxon Valdez Oil Spil', Journal of Legal Studies, 23, 1-39.

Gollier, C. (2005), 'Some Aspects of the Economics of Catastrophe Risk Insurance', in OECD, Catastrophic Risks and Insurance, Paris: OECD, pp. 13-30.

Gron, A. and A.O. Sykes (2002), 'A Role for Government' Regulation, 25, 44-51.

Grossman, D.A. (2003), 'Warming Up to a Not-so-radical Idea: Tort-based Climate Change Litigation', Columbia Journal of Environmental Law, 28, 1-61.

Hankey, S. (1994), 'Claims Made Policies and Choice of Law in the European Union', International Insurance Law Review, 267.

Hansson, I. and G. Skogh (1987), 'Moral Hazard and Safety Regulation', Geneva Papers on Risk and Insurance, 12,132-44.

Harrison, D. and Daniel L. Rubinfeld (1978), 'Hedonic House Prices and the Demand for Clean Air', Journal of Environmental Economics and Management, 5, 81-102.

Hausman, J.A. (1993), Contingent Valuation: A Critical Assessment, Amsterdam: NorthHolland.

Hay, J. (2006), Analyse Économique du Système International CLC/FIPOL Comme Instrument de Prévention des Marées Noires, Thèse de Doctorat, Université de Bretagne Occidentale, 19 Septembre 2006.

Hendrickx, R. (2007), 'Maritime Oil Pollution: An Empirical Analysis', in M. Faure and A. Verheij (eds), Shifts in Compensation for Environmental Damage, Vienna: Ectil, pp. 243-60.

Heyes, A. (2001), The Law and Economics of the Environment, Cheltenham, UK and Northampton, MA, USA: Edward Elgar.

Heyes, A. and C. Liston-Heyes (1998), 'Subsidy to Nuclear Power through Price-Anderson Liability Limit: Comment', Contemporary Economic Policy, 16 (1), 122-4.

Hoch, I. and J. Drake (1974), 'Wages Climate and the Quality of Life', Journal of Environmental Economics and Management, 1, 268-95.

Hyde, C.E., G.C. Rausser and L.K. Simon (2000), 'Regulating Multiple Polluters: Deterrence and Liability Allocation', International Economic Review, 41 (2), 495-521.

Hylton, K.M. (2002), 'When Should we Prefer Tort Law to Environmental Regulation?', Washburn Law Journal, 41, 515-43.

Jost, P.J. (1996), 'Limited Liability and the Requirement to Purchase Insurance', International Review of Law and Economics, 16, 259-76.

Kaplow, L. (1986), 'An Economic Analysis of Legal Transition', Harvard Law Review, 99, 509-617.

Kaplow, L. (1991), 'Incentives and Government Relief for Risk', Journal of Risk and Uncertainty, 4, 167-75.

Kapp, W. (1970), 'Environmental Disruption and Social Costs, a Challenge to Economics', Kyklos, 23, 833-43.

Karten, W.T. (1997), 'How to Expand the Limits of Insurability', The Geneva Papers on Risk and Insurance, 22, 515-22.

Katzman, M. (1988), 'Pollution Liability Insurance and Catastrophic Environmental Risk', Journal of Risk and Insurance, 55, 75-100. 
Kaye, D. (1982), 'The Limits of the Preponderence of the Evidence Standard: Justifiable Naked Statistical Evidence and Multiple Causation', American Bar Foundation Research Journal, 7, 487-516.

Kerkmeester, H. (1993), 'De Betekenis van het Waarschijnlijkheidsbegrip voor de Aansprakelijkheid uit Onrechtmatige Daad: Meijers Geactualiseerd (The Meaning of the Concept Probability from Tort Law: Meijers Actualized)', Weekblad voor Privaatrecht, Notariaat en Registratie, 6111, 767-73.

Ketchum, L. (1985), 'Epidemiologic Tables Law Ground Work for Future Radiogenic Cancer Claims', The Journal of Nuclear Medicine, 26, 967-72.

Kolstad, C.D., T.S. Ulen and G.V. Johnson (1990), 'Ex Post Liability for Harm vs. Ex Ante Safety Regulation: Substitutes or Complements?', American Economic Review, 80, 888-901.

Kornhauser, L.A. and R.L. Revesz (1989), 'Sharing Damages among Multiple Tortfeasors', Yale Law Journal, 98, 831-84.

Kornhauser, L.A. and R.L. Revesz (1990), 'Apportioning Damages among Potentially Insolvent Actors', Journal of Legal Studies, 19, 617-51.

Kornhauser, L.A. and R.L. Revesz (1994), 'Multi-defendant Settlements: The Impact of Joint and Several Liability', Journal of Legal Studies, 23, 41-76.

Kornhauser, L.A. and R.J. Revesz (1998), 'Joint and Several Liability', in P. Newman (ed.), The New Palgrave Dictionary of Economics and the Law, London: Macmillan, pp. 371-6.

Krutilla, J.V. (1967), 'Conservation Reconsidered', American Economic Review, 57, 777-86.

Kunreuther, H. (1996), 'Mitigating Disaster Losses through Insurance', Journal of Risk and Uncertainty, 12, 171-87.

Kunreuther, H. (2006), 'Has the Time Come for Comprehensive Natural Disaster Insurance?', in R.J. Daniels, D.F. Kettl and H. Kunreuther (eds), On Risk and Disaster: Lessons from Hurricane Katrina, Philadelphia: University of Pennsylvania Press, 175-201.

Kunreuther, H., N. Doherty and A. Kleffner (1992), 'Should Society Deal with the Earthquake Problem?', Regulation - The Cato Review of Business and Government, 15/2.

Kunreuther, H. and P. Freeman (2001), 'Insurability, Environmental Risks and the Law', in A. Heyes (ed.), The Law and Economics of the Environment, Cheltenham, UK and Northampton, MA, USA: Edward Elgar, pp. 302-18.

Kunreuther, H. and R. Gowda (1990), Integrating Insurance and Risk Management for Hazardous Wastes, Dordrecht: Kluwer Academic Publishers.

Kunreuther, H., R. Hogarth and J. Meszaros (1993), 'Insurer Ambiguity and Market Failure', Journal of Risk and Uncertainty, 7, 71-87.

Landes, W.M. and R.A. Posner (1983), 'Causation in Tort Law: An Economic Approach', Journal of Legal Studies, 12, 109-34.

Landes, W.M. and R.A. Posner (1984), 'Tort Law as a Regulatory Regime for Catastrophic Personal Injuries', Journal of Legal Studies, 13, 417-34.

Lewis, T.R. and D.E.M. Sappington (2001), 'Horizontal Vicarious Liability', in A. Heyes (ed.), The Law and Economics of the Environment, Cheltenham, UK and Northampton, MA, USA: Edward Elgar, 71-91.

Libecap, G.D. and S.N. Wiggins (1984), 'Contractual Responses to the Common Pool: Prorationing of Crude Oil Production', American Economic Review, 74, 87-98.

Lidgren, K. and G. Skogh (1996), 'Extended Producer Responsibility: Recycling, Liability, and Guarantee Funds', Geneva Papers on Risk and Insurance, 21, 170-81.

Lomas, O. (1989), 'The Prosecution of Marine Oil Pollution Offences and the Practice of Insuring against Fines', Journal of Environmental Law, 1, 48-64.

Makdisi, J. (1989), 'Proportional Liability: A Comprehensive Rule to Apportion Tort Damages Based on Probability', North Carolina Law Review, 67, 1063-101.

Maler, K.G. (1977), 'A Note on the Use of Property Values in Estimating Marginal Willingness to Pay for Environmental Quality', Journal of Environmental Economics and Management, 4, 355-69.

Meddler, F. and R. Moselly (1985), Medical Effects of Ionising Radiation, Orlando: Grune \& Stratton. 
Michelman, F.I. (1971), 'Pollution as a Tort: A Non-accidental Perspective on Calabresi's Costs', Yale Law Journal, 85, 647-86.

Miller, C. (2006), 'Causation in Personal Injury: Legal or Epidemiological Common Sense?', Legal Study, 26(4), 545-69.

Mishan, E.J. (1971a), 'The Post War Literature on Externalities: An Interpretative Essay', Journal of Economic Literature, 9, 1-25.

Mishan, E.J. (1971b), 'Pangloss on Pollution', Swedish Journal of Economics, 73, 11320.

Monti, A. (2001), 'Environmental Risk: A Comparative Law and Economics Approach to Liability and Insurance', European Review of Private Law, 1, 51-79.

Nelson, B.J. (1978), Economic Analysis of Transportation Noise Abatement, Cambridge, MA: Ballinger.

Nichols, E. and A. Wildavsky (1987), 'Nuclear Power Regulation: Seeking Safety, Doing Harm?', Regulation, 11(1), 45-53.

Nieuwenhuis, H. (2006), 'Eurocausality', in H. Tiberg et al. (ed.), Essays on Tort, Insurance, Law and Society in Honour of Bill W. Dufwa, Stockholm: Jure förlag AB, pp. 847-71.

Oates, W.E. (1983), 'The Regulation of Externalities: Efficient Behaviour by Sources and Victims', Public Finance, 38(3), 362-75.

Ogus, A.I. (1994), Regulation: Legal Form and Economic Theory, Oxford: Oxford Clarendon Press.

Ogus, A. (2007), 'The Relationship between Regulation and Tort Law: Goals and Strategies', in W.H. van Boom, M. Lukas and S.H.R. Kissling (eds), Tort Law and Regulatory Law, Vienna: Springer, pp. 377-89.

Ott, C. and H.-B. Schäfer (1997), 'Negligence as Untaken Precaution, Limited Information and Efficient Standard Formation in the Civil Liability System', International Review of Law and Economics, 1, 15-29.

Paté-Cornell, M.E. (1987), 'Risk Analysis and Relevance of Uncertainties in Nuclear Safety Decisions', in E.E. Bailey (ed.), Public Regulation: New Perspectives on Institutions and Policies. MIT Press Series on the Regulation of Economic Activity, no. 14, Cambridge, MA: MIT Press, pp. 227-53.

Pigou, A.C. (1951), A Study in Public Finance, London: Macmillan.

Pommerehne, W.W. (1988), 'Measuring Environmental Benefits: A Comparison of Hedonic Technique and Contingent Valuation', in D. Bös, M. Rose and C. Seidl (eds), Welfare and Efficiency in Public Economics, Berlin: Springer, pp. 363-400.

Posner, R. (1972), 'A Theory of Negligence', Journal of Legal Studies, 1, 29-96.

Pozzo, B. (1996), 'The Liability Problem in Modern Environmental Statutes', European Review of Private Law, 4, 112-29.

Priest, G. (1987), 'The Current Insurance Crisis and Modern Tort Law', Yale Law Journal, 97, 1521-90.

Priest, G. (1996), 'The Government, the Market and the Problem of Catastrophic Loss', Journal of Risk and Uncertainty, 12, 219-37.

Radetzki, M. and M. Radetzki (2000), 'Private Arrangements to Cover Large-scale Liabilities caused by Nuclear and other Industrial Catastrophes', The Geneva Papers on Risk and Insurance, 25, 180-95.

Revesz, R. and R. Stewart (1995), Analysing Superfund, Economics, Science and Law, Washington, DC: RFF Press.

Rhoads, T.A. and J.F. Shogren (2001), 'Coasean Bargaining in Collaborative Environmental Policy', in A. Heyes (ed.), The Law and Economics of the Environment, Cheltenham, UK and Northampton, MA, USA: Edward Elgar, pp. 18-43.

Rizzo, M.J. and F.S. Arnold (1980), 'Causal Aportionment in the Law of Torts: An Economic Theory', Columbia Law Review, 80, 1399-429.

Rizzo, M.J. and F.S. Arnold (1986), 'Causal Aportionment: Reply to the Critics', Journal of Legal Studies, 15, 219-26.

Robinson, G.O. (1985), 'Probabilistic Causation and Compensation for Tortuous Risk', Journal of Legal Studies, 14, 779-98. 
Rogge, J. (1997), Les Assurances en Matière d'Environnement, The Hague: Kluwer Law International.

Rose-Ackerman, S. (1992a), Re-thinking the Progressive Agenda, the Reform of the American Regulatory State, New York, NY: The Free Press.

Rose-Ackerman, S. (1992b), 'Environmental Liability Law', in T.H. Tietenberg (ed.), Innovation in Environmental Policy, Economic and Legal Aspects of Recent Developments in Environmental Enforcement and Liability, Aldershot, UK and Brookfield, MA, USA: Edward Elgar, pp. 223-43.

Rose-Ackerman, S. (1995a), 'Public Law versus Private Law in Environmental Regulation: European Union Proposals in the Light of United States and German Experience', Review of European Community and International Environmental Law, 4, 312-32.

Rose-Ackerman, S. (1995b), Controlling Environmental Policy: The Limits of Public Law in Germany and the United States, New Haven, CT: Yale University Press.

Rose-Ackerman, S. (1996), 'Public Law versus Private Law in Environmental Regulation: European Union Proposals in the Light of United States and German Experiences', in E. Eide and R. Van den Bergh (eds), Law and Economics of the Environment, Oslo: Juridisk Forlag, pp. 13-39.

Rosenberg, D. (1984), 'The Causal Connection in Mass Exposure Cases: A "Public Law" Vision of the Tort System', Harvard Law Review, 97, 851-929.

Schmitz, P.W. (2000), 'On the Joint Use of Liability and Safety Regulation', International Review of Law and Economics, 20, 371-82.

Schulze, W. and R. D’Arge (1974), 'The Coase Proposition, Information Constraints, and Long Run Equilibrium', American Economic Review, 74, 763-72.

Schwartz, A. (2000), 'Statutory Interpretation, Capture and Tort Law: The Regulatory Compliance Defence', American Law \& Economics Review, 1, 1-57.

Schwartz, G. (1997), 'Mixed Theories of Tort Law: Affirming both Deterrence and Corrective Justice', Texas Law Review, 75, 1801-34.

Schwarze, R. and G. Wagner (2004), 'In the Aftermath of Dresden: New Directions in German Flood Insurance', Geneva Papers on Risk and Insurance, 29, 154-68.

Segerson, K. (1993), 'Liability Transfers: An Economic Analysis of Buyer and Lender Liability', Journal of Environmental Economics and Management, 25, 46-63.

Settle, C., T.M. Hurley and J.F. Shogren (2001), 'Citizen Suits', in A. Heyes (ed.), The Law and Economics of the Environment, Cheltenham, UK and Northampton, MA, USA: Edward Elgar, pp. 217-48.

Shavell, S. (1979), 'On Moral Hazard and Insurance', Quarterly Journal of Economics, 93, 541-62.

Shavell, S. (1980a), 'An Analysis of Causation and the Scope of Liability in the Law of Torts', Journal of Legal Studies, 9, 463-516.

Shavell, S. (1980b), 'Strict Liability versus Negligence', Journal of Legal Studies, 9, 1-25.

Shavell, S. (1984a), 'Liability for Harm versus Regulation of Safety', Journal of Legal Studies, 13, 357-74

Shavell, S. (1984b), 'A Model of the Optimal Use of Liability and Safety Regulation', Rand Journal of Economics, 15, 271-80.

Shavell, S. (1985), 'Uncertainty over Causation and the Determination of Civil Liability', Journal of Law and Economics, 28, 587-609.

Shavell, S. (1986), 'The Judgment-proof Problem', International Review of Law and Economics, 6, 43-58.

Shavell, S. (1987a), 'The Optimal Use of Nonmonetary Sanctions as a Deterrent', American Economic Review, 77, 584-92.

Shavell, S. (1987b), Economic Analysis of Accident Law, Cambridge, MA: Harvard University Press.

Shavell, S. (1992), 'Liability and the Incentive to Obtain Information about Risk', Journal of Legal Studies, 21, 259-70.

Sigman, H. (1998), 'Liability Fending and Superfund Clean-up Remedies', Journal of Environmental Economics and Management, 35, 205-24. 
Sigman, H. (2001), 'Environmental Liability in Practice: Liability for Clean-up of Contaminated Sites under Superfund', in A. Heyes (ed.), The Law and Economics of the Environment, Cheltenham, UK and Northampton, MA, USA: Edward Elgar, pp. 116-49.

Skogh, G. (1982), 'Public Insurance and Accident Prevention', International Review of Law and Economics, 2, 67-80.

Skogh, G. (1989a), 'The Combination of Private and Public Regulation of Safety', in M. Faure and R. Van den Bergh (eds), Essays in Law and Economics: Corporations, Accident Prevention and Compensation for Losses, Antwerpen: Maklu, pp. 87-101.

Skogh, G. (1989b), 'The Transactions Cost Theory of Insurance, Contract Impediments and Costs', Journal of Risk and Insurance, 65, 726-32.

Skogh, G. and D. Rehme (1998), 'An Economic Analysis of a Swedish Environmental Liability Case', European Journal of Law and Economics, 5, 167-77.

Slovic, P., H. Kunreuther and G. White (2000), 'Decision Processes, Rationality and Adjustment to Natural Hazards', in P. Slovic (ed.), The Perception of Risk, London: Earthscan, pp. 1-31.

Spier, J. (2006), 'Legal Aspects of Global Climate Change and Sustainable Development', Revista para el Analisi del Derecho (http://www.indret.com/pdf/346_en.pdf).

Spier, J. and O.A. Haazen (1996), Aansprakelijkheidsverzekeringen op Claims-Made-Grondslag (Liability Insurance on Claims-Made-Grounds), Deventer: Kluwer.

Stahel, W.R. (1997), 'Some Thoughts on Sustainability, Insurability and Insurance', Geneva Papers on Risk and Insurance, 22, 477-95.

Tan, A. (2006), Vessel-Source Marine Pollution: The Law and Politics of International Regulation, Cambridge: Cambridge University Press.

Tietenberg, T.H. (1989), 'Indivisible Toxic Torts: The Economics of Joint and Several Liability', Land Economics, 65, 305-19.

Tol, R.S.J. and R. Verheyen (2004), 'State Responsibility and Compensation for Climate Change Damages - A Legal and Economic Assessment', Energy Policy, 32, 1109-30.

Trebilcock, M.J. (1987), 'The Social Insurance - Deterrence Dilemma of Modern North American Tort Law: A Canadian Perspective on the Liability Insurance Crisis', San Diego Law Review, 24, 929-1002.

Trebilcock, M.J. and R. Winter (1997), 'The Economics of Nuclear Accident Law', International Review of Law and Economics, 17, 215-43.

Tribe, B. (1971), 'Trial by Mathematics: Precision and Rituals in the Legal Process', Harvard Law Review, 84, 1329-93.

Vanden Borre, T. (1999), 'Channelling of Liability: A few Juridical and Economic Views on an Inadequate Legal Construction', in N.L.J.T. Horbach (ed.), Contemporary Developments in Nuclear Energy Law: Harmonizing Legislation in CEE/NIS, The Hague: Kluwer Law International, pp. 13-39.

Vanden Borre, T. (2001), Efficiënte preventie en compensatie van catastroferisico's - het voorbeeld van schade door kernongevallen, Antwerpen: Intersentia.

Vanden Borre, T. (2007), 'Shifts in Governance in Compensation for Nuclear Damage, 20 Years after Chernobyl', in M. Faure and A. Verheij (eds), Shifts in Compensation for Environmental Damage, Vienna: Springer, pp. 261-311.

Van Egteren, H. and R.T. Smith (2001), 'International Harmonization of Environmental Law: Theory with Application to the European Union', in A. Heyes, The Law and Economics of the Environment, Cheltenham, UK and Northampton, MA, USA: Edward Elgar, pp. 280-301.

Van Egteren, H. and R.T. Smith (2002), 'Environmental Regulations under Simple Negligence or Strict Liability', Environmental and Resource Economics, 21, 369-96.

Van Egteren, H., R.T. Smith and A. Eckert (2006), 'Environmental Liability and Harmonisation in the Presence of Transboundary Effects and Hidden Assets', European Journal of Law and Economics, 22, 143-63.

Van Egteren, H., R.T. Smith and D. McAfee (2004), 'Harmonisation of Environmental Regulations when Firms are Judgement-proof', European Journal of Law and Economics, 17, 139-64. 


\section{Tort law and economics}

Van Mieghem, E. (1988), Het Kankerrisico bij Professionele Blootstelling aan Lage Dosissen Ioniserende Straling, Leuven: Universitaire Pers.

Verheij, A. (2007), 'Shifts in Governance: Oil Pollution', in M. Faure and A. Verheij (eds), Shifts in Compensation for Environmental Damage, Vienna: Ectil, pp. 133-95.

Verheyen, R. (2005), Climate Change Damage and International Law: Prevention Duties and State Responsibility, Leiden: Martinus Nijhoff Publishers (Brill Publishers).

Viscusi, W.K. (1991), 'The Dimensions of the Product Liability Crisis', Journal of Legal Studies, 20, 147-77.

Wagner, G. (1991), 'Umwelthaftung und Versicherung', Versicherungsrecht, 249-60.

Wagner, G. (1992), 'Die Zukunft der Umwelthaftpflichtversicherung', Versicherungsrecht, 261-72.

Wagner, G. (1996), 'Umwelthaftung und Versicherung', in M. Ahrens and J. Simon (eds), Umwelthaftung, Risikosteuerung und Versicherung, Berlin: Erich Schimdt Verlag, pp. 97-146.

Wagner, G. (1999), 'Haftung und Versicherung als Instrumente der Techniksteuerung', Versicherungsrecht, 1441-80.

Wang, H. (2007), 'Shifts in Governance in the International Regime of Marine Oil Pollution Compensation: Legal History Perspective', in M. Faure and A. Verheij (eds), Shifts in Compensation for Environmental Damage, Vienna: Ectil, pp. 197-241.

Wittman, D.A. (1977), 'Prior Regulation versus Post Liability: The Choice between Input and Output Monitoring', Journal of Legal Studies, 6, 193-211.

Zeckhauser, R. (1996), 'The Economics of Catastrophes', Journal of Risk and Uncertainty, $12,113-40$ 